\title{
Neural Cell Adhesion Molecule-Associated Polysialic Acid Regulates Synaptic Plasticity and Learning by Restraining the Signaling through GluN2B-Containing NMDA Receptors
}

\author{
Gaga Kochlamazashvili, ${ }^{1,3 *}$ Oleg Senkov, ${ }^{2 *}$ Sergei Grebenyuk, ${ }^{4 *}$ Catrina Robinson, ${ }^{5 *}$ Mei-Fang Xiao, ${ }^{1}$ \\ Katharina Stummeyer, ${ }^{6}$ Rita Gerardy-Schahn, ${ }^{6}$ Andreas K. Engel, ${ }^{2}$ Larry Feig, ${ }^{7}$ Alexey Semyanov, ${ }^{4,8}$ \\ Vishnu Suppiramaniam, ${ }^{5}$ Melitta Schachner, ${ }^{1,9,10}$ and Alexander Dityatev ${ }^{1,2,3,5}$ \\ ${ }^{1}$ Zentrum für Molekulare Neurobiologie Hamburg and ${ }^{2}$ Department of Neurophysiology and Pathophysiology, University Medical Center Hamburg- \\ Eppendorf, 20246 Hamburg, Germany, ${ }^{3}$ Department of Neuroscience and Brain Technologies, Italian Institute of Technology, 16163 Genova, Italy, \\ ${ }^{4}$ Neuronal Circuit Mechanisms Research Group, RIKEN Brain Science Institute, Hirosawa, Wako-shi, Saitama, 351-0198, Japan, ${ }^{5}$ Department of Pharmacal \\ Sciences, Harrison School of Pharmacy, Auburn University, Auburn, Alabama 36849, ${ }^{6}$ Zelluläre Chemie, Medizinische Hochschule Hannover, 30625 \\ Hannover, Germany, ${ }^{7}$ Departments of Biochemistry and Neuroscience, Sackler School of Graduate Biomedical Sciences, Tufts University School of \\ Medicine, Boston, Massachusetts 02111, ${ }^{8}$ University of Nizhny Novgorod, Nizhny Novgorod, 603950, Russia, ${ }^{9}$ Keck Center for Collaborative Neuroscience \\ and Department of Cell Biology and Neuroscience, Rutgers University, Piscataway, New Jersey 08854 , and ${ }^{10}$ Center for Neuroscience, Shantou University \\ Medical College, Shantou 515041, China
}

The neural cell adhesion molecule (NCAM) is the predominant carrier of $\alpha 2,8$ polysialic acid (PSA) in the mammalian brain. Abnormalities in PSA and NCAM expression are associated with schizophrenia in humans and cause deficits in hippocampal synaptic plasticity and contextual fear conditioning in mice. Here, we show that PSA inhibits opening of recombinant NMDA receptors composed of GluN1/2B (NR1/NR2B) or GluN1/2A/2B (NR1/NR2A/NR2B) but not of GluN1/2A (NR1/NR2A) subunits. Deficits in NCAM/PSA increase GluN2Bmediated transmission and $\mathrm{Ca}^{2+}$ transients in the $\mathrm{CA} 1$ region of the hippocampus. In line with elevation of GluN2B-mediated transmission, defects in long-term potentiation in the CA1 region and contextual fear memory in NCAM/PSA-deficient mice are abrogated by application of a GluN2B-selective antagonist. Furthermore, treatment with the glutamate scavenger glutamic-pyruvic transaminase, ablation of Ras-GRF1 (a mediator of GluN2B signaling to $38 \mathrm{MAPK}$ ), or direct inhibition of hyperactive $38 \mathrm{MAPK}$ can restore impaired synaptic plasticity in brain slices lacking PSA/NCAM. Thus, PSA carried by NCAM regulates plasticity and learning by inhibition of the GluN2B-Ras-GRF1-p38 MAPK signaling pathway. These findings implicate carbohydrates carried by adhesion molecules in modulating NMDA receptor signaling in the brain and demonstrate reversibility of cognitive deficits associated with ablation of a schizophrenia-related adhesion molecule.

\section{Introduction}

The neural cell adhesion molecule (NCAM) is expressed by all cell types in the nervous system, where it promotes neuronneuron and neuron-glia adhesion via homophilic and hetero-

\footnotetext{
Received Nov. 23, 2009; revised Jan. 24, 2010; accepted Feb. 15, 2010.

M.S. was supported by the New Jersey Commission for Spinal Cord Research. M.S. and A.D. were supported by the Deutsche Forschungsgemeinschaft. R.G.-S. and K.S. received financial support from the European Community (FP 6: PROMEMORIA, Contract no. LSHM-CT-2005-512012). We thank Harold Cremer for NCAM-deficient mice, Kodeeswaran Parameshwaran for help with single-channel analysis, Achim Dahlmann for genotyping, and Eva Kronberg for animal care. The vectors for expression of the GluN subunits were kind gifts from Peter Seeburg (Max-Planck Institute for Medical Research, Heidelberg, Germany), and Kevin Holmes and Gregory Dekaban (both from University of Western Ontario, London, Ontario, Canada). NVPAAM077 was a kind gift from Dr. Yves Auberson at Novartis Institutes for BioMedical Research.

${ }^{*}$ G.K. and O.S. contributed equally to this work.

"S.G. and C.R. contributed equally to this work.

Correspondence should be addressed to either of the following: Alexander Dityatev, Department of Neuroscience and Brain Technologies, The Italian Institute of Technology, Via Morego, 30, 16163 Genova, Italy, E-mail: alexander.dityatev@iit.it; or Melitta Schachner, Zentrum für Molekulare Neurobiologie, Universitätsklinikum HamburgEppendorf, Martinistrasse 85, D-20251 Hamburg, Germany, E-mail: melitta.schachner@zmnh.uni-hamburg.de.

0 . Senkov's present address: Department of Clinical Neurobiology, University of Heidelberg, 69120 Heidelberg, Germany.

DOI:10.1523/JNEUROSCI.5806-09.2010

Copyright $\odot 2010$ the authors $\quad 0270-6474 / 10 / 304171-13 \$ 15.00 / 0$
}

philic interactions with other cell adhesion and extracellular matrix molecules. It is involved in signal transduction and critical developmental events, such as cell migration and proliferation, neurite outgrowth and fasciculation, synaptogenesis and synaptic plasticity (Dityatev et al., 2000; Maness and Schachner, 2007). Functions of NCAM depend on its glycosylation, particularly on polysialylation, i.e., attachment of long homopolymers of $\alpha 2,8$ linked sialic acid residues, known as polysialic acid (PSA) (Rutishauser and Landmesser, 1996; Dityatev et al., 2004; Weinhold et al., 2005). PSA expression is regulated in an age-, cell type- and activity-dependent manner, being highest during early development and in brain regions associated with neuroplasticity in the adult. A growing body of evidence has implicated NCAM and PSA as risk factors for major neuropsychiatric and neurodegenerative disorders, such as schizophrenia, bipolar disorder, depression, anxiety disorder, and Alzheimer's disease (Brennaman and Maness, 2008). This is in line with increasing appreciation of the roles played in brain malfunctions by other cell adhesion molecules, such as the NCAM-associated cell adhesion molecule L1 and neuroligins (Dahme et al., 1997; Südhof, 2008). Particu- 
larly noteworthy are the drastically decreased expression of polysialylated NCAM (PSA-NCAM) in hippocampi of patients with schizophrenia (Barbeau et al., 1995) and a link between NCAM and neurocognitive changes in schizophrenia (Sullivan et al., 2007).

These data agree with the widely recognized role of NCAM and its associated PSA as an important mediator of synaptic plasticity in the adult (Lüthi et al., 1994; Muller et al., 1996; Bukalo et al., 2004). Learning and synaptic plasticity in vitro and in vivo are altered in the CA1 and CA3 hippocampal subfields and/or in the dentate gyrus of mice deficient for NCAM (Cremer et al., 1994, 1998; Muller et al., 1996; Senkov et al., 2006; Stoenica et al., 2006). In different types of synapses, synaptic plasticity is modulated by NCAM through either PSA-dependent or PSA-independent mechanisms. Enzymatic removal of NCAM-associated PSA and genetic ablation of polysialyltransferase ST8SiaIV-required for polysialylation of NCAM in the adult hippocampus-lead to learning defects and impairment of long-term potentiation (LTP) and long-term depression (LTD) in the CA1 region of the hippocampus, but not in mossy fiber-CA3 synapses or in perforant path synapses of the dentate gyrus (Becker et al., 1996; Muller et al., 1996; Eckhardt et al., 2000; Senkov et al., 2006). Application of soluble PSA-NCAM to acute slices of NCAMdeficient mice restores normal CA1 LTP and improves contextual fear memory (Senkov et al., 2006). Since application of non-polysialylated NCAM is not effective in restoring normal CA1 LTP, the combined data indicate that PSA is both necessary and sufficient for normal induction of CA1 LTP.

However, the mechanisms by which NCAM regulates synaptic plasticity in a PSA-dependent manner have remained elusive. In light of data suggesting that PSA prevents activation of GluN2B (former NR2B; for the modern nomenclature, see Collingridge et al., 2009)-containing NMDA receptors at low concentrations of glutamate (Hammond et al., 2006), we have now investigated GluN2B-mediated neurotransmission in NCAM/ PSA-deficient hippocampal slices and its impact on synaptic plasticity and contextual fear learning in NCAM/PSA-deficient mice. By restoring plasticity and learning in NCAM/PSAdeficient mice through inhibition of GluN2B and downstream signaling, we demonstrate reversibility of abnormalities associated with the deficit in a schizophrenia-related cell adhesion molecule.

\section{Materials and Methods}

Animals. Constitutively NCAM-deficient $\left(\mathrm{NCAM}^{-/-}\right)$mice (Cremer et al., 1994) and their wild-type $\left(N C A M^{+/+}\right)$littermates were inbred onto the C57BL/6J genetic background for 10 generations. Two- to 3-monthold mice of both sexes were used for electrophysiological and biochemical experiments. Three-month-old Ras-GRF1-deficient mice (Giese et al., 2001), inbred onto the C57BL/6J genetic background for at least 6 generations, were used for electrophysiological recordings.

For behavioral experiments, we used 3- to 5-month-old $\mathrm{NCAM}^{-/-}$ males and their littermates. At least 1 week before starting the experiments, mice were transferred from the animal facility of the Zentrum für Molekulare Neurobiologie to a small vivarium at the Department of Neurophysiology and Pathophysiology, where they were housed individually with food and water ad libitum on a reversed 12:12 light/dark cycle (light on at 11:00 P.M., and all behavioral experiments were performed in the afternoon, during the dark phase of the cycle when mice are active) under constant temperature $\left(22 \pm 1^{\circ} \mathrm{C}\right)$ and humidity $(55 \pm 5 \%)$. All treatments and behavioral procedures were approved by the Food and Veterinary Office in a governmental body for Social Affairs, Family, Health and Consumer Protection in Hamburg, by the Office of Animal Welfare at the Department of Veterinary Public Health, Nutrition and
Food Safety in Rome, or have been performed according to RIKEN regulations.

Single-channel recordings from recombinant NMDA receptors. GluN1-1a with an HA tag in the pEGFP-N1 vector (Holmes et al., 2002) was a kind gift from Kevin Holmes and Gregory Dekaban (University of Western Ontario, London, Ontario, Canada). GluN2A in the pRK5 vector and GluN2B in the pRK7 vector were kind gifts of Peter Seeburg (Max-Planck Institute for Medical Research). Chinese hamster ovary (CHO) cells were transiently cotransfected with $1 \mu \mathrm{g}$ of GluN1 and $1 \mu \mathrm{g}$ of GluN2A, or GluN2B, or $0.5 \mu \mathrm{g}$ of GluN2A plus $0.5 \mu \mathrm{g}$ of GluN2B cDNAs per a well of 6-well plates using Lipofectamine (Invitrogen), as described by the manufacturer. The expression of GluNs was confirmed by Western blotting. The transfected $\mathrm{CHO}$ cells were harvested $48 \mathrm{~h}$ after transfection to prepare the plasma membrane fraction for reconstitution in lipid bilayers using the "tip-dip" method as described previously (Hammond et al., 2006), with minor modifications. The bilayer formation was initiated by successive transfer of two monolayers onto the tip of the patch pipette in an asymmetric saline condition with "outside-out" configuration. The bath solution contained pseudoextracellular fluid composed of the following (in mM): $125 \mathrm{NaCl}, 5 \mathrm{KCl}, 1.25 \mathrm{NaH}_{2} \mathrm{PO}_{4}, 0.001$ glycine, and 5 Tris $\mathrm{HCl}$. The pseudointracellular fluid, consisting of the following (in $\mathrm{mm}$ ): $110 \mathrm{KCl}, 4 \mathrm{NaCl}, 2 \mathrm{NaHCO}_{3}, 1 \mathrm{MgCl}_{2}, 0.1 \mathrm{CaCl}_{2}$, and $23-\mathrm{N}$ morpholinopropanesulfonic acid, was used as the pipette solution. Single-channel currents were elicited by application $0.3,1$, and $3 \mu \mathrm{M}$ glutamate (here and elsewhere unless specified otherwise, Sigma). Increasing glutamate concentrations elevated the open probability rather than the conductance of NMDA receptors. GluN1/2A, GluN1/2B, and GluN1/2A/2B currents were recorded at $+85 \mathrm{mV},+92 \mathrm{mV}$ and $+75 \mathrm{mV}$, respectively. At these voltages we observed patches containing only single channels with many events as possible and a stable base line. After recordings from channels derived from cells transfected with GluN1 plus GluN2A or GluN1 plus GluN2B subunits, $10 \mu \mathrm{M}$ APV or $0.25 \mu \mathrm{M}$ Ro 25-6981 was added to block activity, respectively, and, thus, to confirm the identity of recorded channels as NMDA receptors. To isolate the activity of GluN1/2A/2B receptors from that of GluN1/2A and GluN1/2B receptors during recordings from channels derived from cells transfected with GluN1 plus GluN2A and GluN2B subunits, $50 \mathrm{~nm} \mathrm{ZnCl}_{2}$ and 0.25 $\mu \mathrm{M}$ Ro 25-6981 were present in the extracellular solution during all recordings. To determine these concentrations of Ro 25-6981 and $\mathrm{ZnCl}_{2}$ (needed to block GluN1/2B and GluN1/2A receptors, respectively), we recorded GluN1/2B single-channel activity $(n=5)$ elicited with $3 \mu \mathrm{M}$ glutamate and tested concentrations of Ro 25-6981 ranging from 0.05 to $0.25 \mu \mathrm{M}$, with increments of $0.05 \mu \mathrm{M}$, until channel activity was completely abolished (Fig. 1 A). Similarly, for GluN1/2A, $3 \mu \mathrm{m}$ glutamate and increasing concentrations of $\mathrm{ZnCl}_{2}(10-50 \mathrm{nM})$ with increments of $10 \mathrm{nM}$ were tested until channels $(n=5)$ were completely blocked (Fig. $1 B)$. After successful inhibition of both GluN1/2B and GluN1/2A receptors with Ro 25-6981 and $\mathrm{ZnCl}_{2}$, respectively, the voltage was changed to ensure that inhibition was not voltage-dependent. APV was added at the end of these recordings to confirm the identity of recorded channels as NMDA receptors. PSA (colominic acid, Fluka) was delivered to the extracellular fluid in increasing concentrations ranging from $1 \mu \mathrm{g} / \mathrm{ml}$ to 10 $\mu \mathrm{g} / \mathrm{ml}$, as indicated in the text, in the presence of $3 \mu \mathrm{m}$ glutamate. Data processing of single-channel recordings was performed as described previously (Vaithianathan et al., 2005). Briefly, the all-point-currentamplitude histograms were constructed for 3000 ms traces, 5-6 per patch. The single-channel Po was calculated as $\mathrm{Po}=\mathrm{Ro} /(\mathrm{Rc}+\mathrm{Ro})$, where Rc and Ro represent areas under the current-amplitude histogram corresponding to closed and open states, respectively, fitted with the sum of two Gaussian curves using the Microcal Origin program. The singlechannel chord conductance was calculated as $I_{\mathrm{amp}} /\left(V_{\mathrm{m}}-V_{\text {rev }}\right)$, where $I_{\mathrm{amp}}$ is the single-channel current amplitude at the membrane potential $V_{\mathrm{m}}$ and $\mathrm{V}_{\text {rev }}$ is the reversal potential assumed to be $0 \mathrm{mV}$.

Recordings of NMDA receptor-mediated responses and LTP in hippocampal slices. After brief $\mathrm{CO}_{2}$ sedation, decapitation and removal of the brain, sagittal hippocampal sections were cut with a Leica VT $1000 \mathrm{M}$ vibratome in ice-cold artificial CSF (ACSF) containing the following (in mM): 250 sucrose, $24 \mathrm{NaHCO}_{3}, 25$ glucose, $2.5 \mathrm{KCl}, 1.25 \mathrm{NaH}_{2} \mathrm{PO}_{4}, 2$ $\mathrm{CaCl}_{2}, 1.5 \mathrm{MgCl}_{2}, \mathrm{pH}$ 7.3. The slices were then kept for at least $2 \mathrm{~h}$ before 

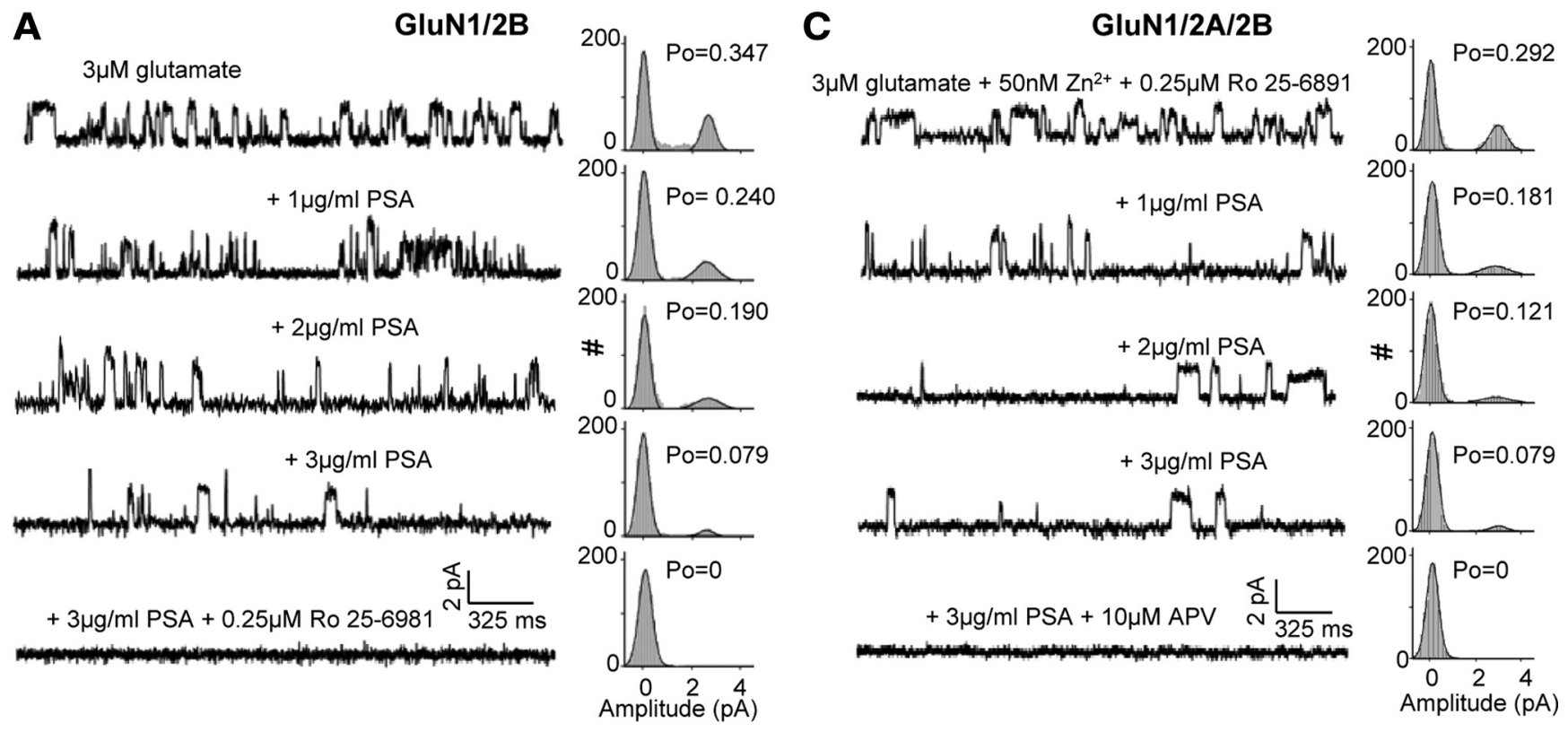

B

\section{GluN1/2A}
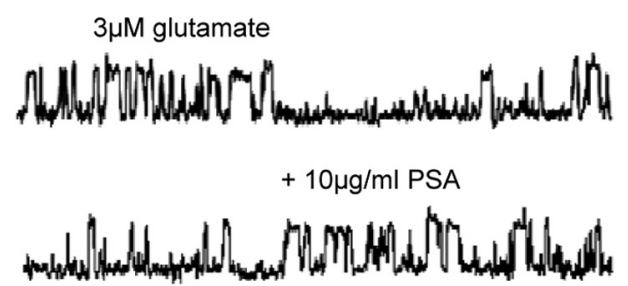

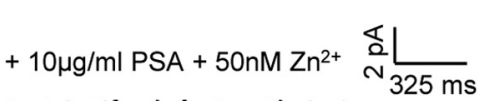

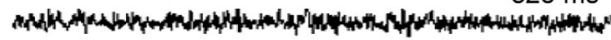

D

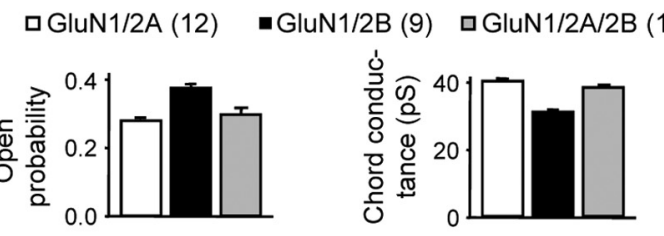

E
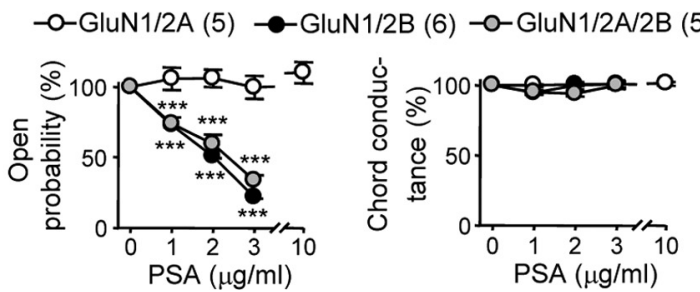

Figure 1. PSA inhibits GluN1/2B and GluN1/2A/2B receptors. $A-C$, Sample traces showing currents from GluN1/2B $(A)$, GluN1/2A $(B)$, and GluN1/2A/2B $(C)$ receptors reconstituted in lipid bilayers and activated by $3 \mu \mathrm{m}$ glutamate in the absence or presence of PSA and NMDA receptor antagonists. Channel activity is evident by upward transitions of the current, which represent the open state. Respective amplitude histograms, with peaks corresponding to the closed and the major open state are shown to the right of each sample trace. The traces illustrate the progressive reduction in the open probability $(\mathrm{Po})$ of single $\mathrm{GluN1} 1 / 2 \mathrm{~B}(\mathrm{~A})$ and $\mathrm{GluN1} / 2 \mathrm{~A} / 2 \mathrm{~B}(\mathrm{C})$ channels in the presence of 1,2 , and $3 \mu \mathrm{g} / \mathrm{ml}$ PSA, respectively. Activities of GluN1/2B, GluN1/2A and GluN1/2A/2B channels were blocked by Ro 25-6981 $(\boldsymbol{A}), \mathrm{Zn}^{2+}(\boldsymbol{B})$, and APV (C), respectively. D, Absolute values of mean + SEM of the open probability and chord conductance of GluN1/2B, GluN1/2A and GluN1/2A/2B channels in the absence of PSA. One-way ANOVA revealed a difference between three types of channels in terms of open probability $(p<0.001)$ and conductance $(p<0.001)$. The probability is higher for GluN1/2B channels compared with GluN1/2A and GluN1/2A/2B $(p<0.001)$, the conductances are distinct for all channels $(p<0.001$; post hoc Bonferroni $t$ test $)$. E, Normalized values of mean + SEM of the open probability and chord conductance of GluN1/2B, GluN1/2A and GluN1/2A/2B channels as a function of PSA concentration. The values of parameters in the absence of PSA were set to $100 \%$. Two-way repeated-measures ANOVA applied either to all three or to GluN1/2B and GluN1/2A/2B receptors revealed the effect on open probability (not on the chord conductance) of PSA $(p<0.01)$ and interaction between PSA and receptor composition $(p<0.05)$. ${ }^{* *} p<0.001$, post hoc Bonferroni $t$ test, significant effects of PSA on GluN1/2B and GluN1/2A/2B receptors compared with control.

the start of recordings at room temperature in carbogen-bubbled ACSF, containing $120 \mathrm{~mm} \mathrm{NaCl}$ instead of $250 \mathrm{~mm}$ sucrose. For isolation of NMDA receptor-mediated field EPSPs (fEPSPs), $\mathrm{MgCl}_{2}$ concentration was lowered to $0.25 \mathrm{~mm}$ during recordings. Recordings were performed in the same solution, in a submerged chamber, at room temperature $\left(22-24^{\circ} \mathrm{C}\right)$. Recordings of fEPSPs were performed in the stratum radiatum of the CA1b subfield with glass pipettes filled with ACSF and having a resistance of $1-2 \mathrm{M} \Omega$. Schaffer collaterals were stimulated with a glass pipette having a resistance of $1 \mathrm{M} \Omega$ and placed $\sim 300 \mu \mathrm{m}$ closer to the CA3 subfield than the recording electrode. Basal synaptic transmission was monitored at $0.05 \mathrm{~Hz}$. The intertheta burst stimulation (TBS) interval was $20 \mathrm{~s}$ and four TBSs were applied to induce LTP. TBS consisted of 8 bursts delivered at $5 \mathrm{~Hz}$. Each burst consisted of four pulses delivered at $100 \mathrm{~Hz}$. Duration of pulses was $0.2 \mathrm{~ms}$ and stimulation strength was set to provide baseline fEPSPs with amplitude of $\sim 50 \%$ from the subthreshold maximum.
The data were recorded at sampling rate of $10 \mathrm{kHz}$, low-pass filtered at $3 \mathrm{kHz}$ and analyzed using EPC10 amplifier and Pulse software (both from Heka). SigmaPlot (Systat Software Inc.) was used for data presentation and digital subtraction of responses elicited by single pulses for precise measurements of paired-pulse facilitation (defined as the ratio between the slopes of fEPSPs elicited by the second and first pulses).

Enzymatic and pharmacological treatments of hippocampal slices. To remove PSA before electrophysiological recordings of LTP, acute hippocampal slices from C57BL/6 J mice were incubated for $2 \mathrm{~h}$ at $35^{\circ} \mathrm{C}$ in 2 $\mathrm{ml}$ of carbogen-bubbled ACSF supplemented by recombinantly produced active (truncated by 245 amino acids) form of PSA-degrading endosialidase of bacteriophage K1F (endoNF; $9.6 \mu \mathrm{g} / \mathrm{ml}$ ) (Stummeyer et al., 2005). The slices incubated without any enzyme or with a mutated (two substituted amino acids) inactive form of endoNF $(9.6 \mu \mathrm{g} / \mathrm{ml})$ (Stummeyer et al., 2005) served as controls. To verify removal of PSA by endoNF and no changes in expression of PSA by inactive endoNF, all 

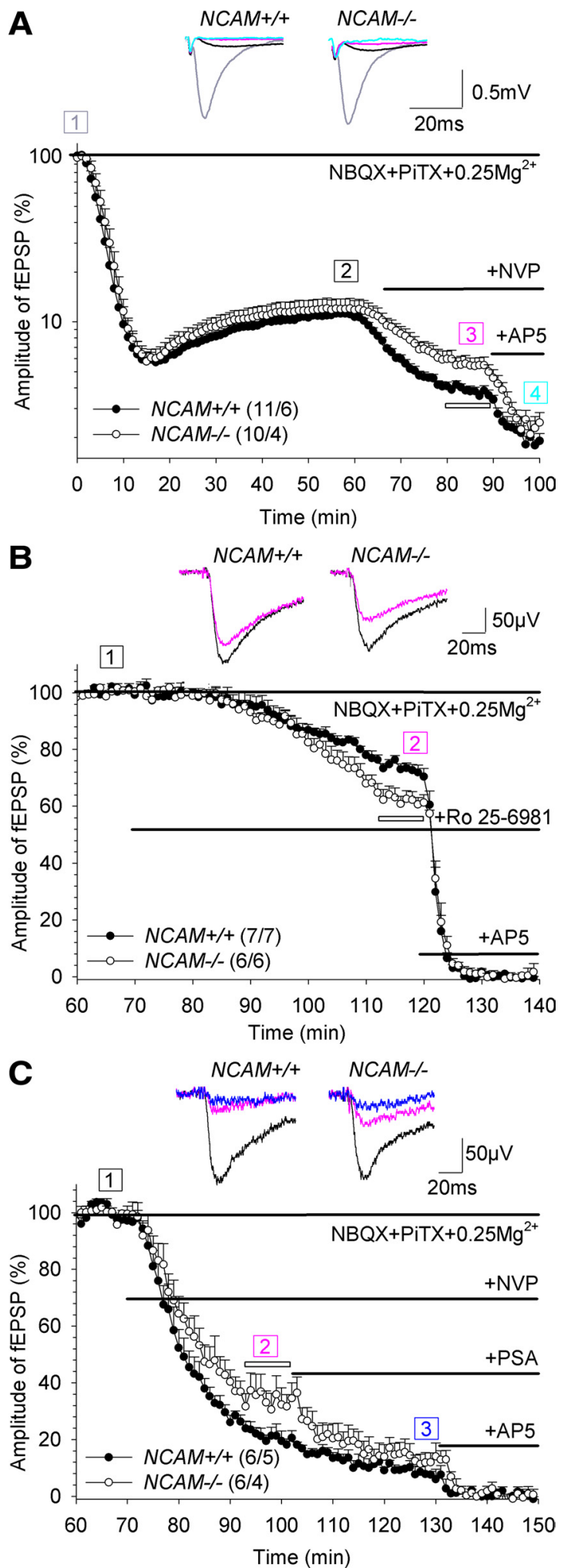

Figure 2. Increased responses mediated by GluN2B in hippocampal slices of $N C A M^{-1-}$ mice. $A$, AMPA receptor-mediated fast component of fEPSP, the amplitude of which was taken as $100 \%$ [1], was blocked by perfusion with ACSF containing $0.25 \mathrm{Mg}^{2+}$, the AMPA/kainate receptor antagonist NBQX and the $\mathrm{GABA}_{A} /$ glycine receptor antagonist picrotoxin (PiTX), leaving the GluN-mediated component [2]. Application of $0.25 \mu \mathrm{m}$ NVP isolated fEPSPs mediated predominantly by GluN2B [3], which could be blocked to $1-1.5 \%$ level by the NMDA receptor antagonist APV $(50 \mu \mathrm{M})$ [4]. To present changes in high-amplitude AMPA receptor-mediated fEPSPs and low amplitude NMDA receptor-mediated fEPSPs in one graph, a logarithmic $Y$-scale is used. The inset shows representative traces corresponding to time intervals color-coded in $\boldsymbol{A}$. treated slices were fixed overnight in $4 \%$ formaldehyde in phosphate buffered saline, $\mathrm{pH} 7.3$, cut in $30 \mu \mathrm{m}$-thick subslices and immunostained for PSA using a monoclonal antibody (clone 735) (Eckhardt et al., 2000). The selected concentration of endoNF guaranteed removal of PSA in all recorded slices (supplemental Fig. 1, available at www.jneurosci.org as supplemental material).

The following drugs were used in our experiments: $[(R)-[(S)-1-(4-$ bromo-phenyl)-ethylamino]-(2,3-dioxo-1,2,3,4-tetrahydro-quinoxalin5-yl)-methyl]-phosphonic acid (NVP-AAMO77, $0.25 \mu \mathrm{M}$, generously supplied by Dr. Yves Auberson from Novartis Pharmaceuticals), an antagonist producing preferential inhibition of GluN2A-containing receptors; $R$ - $\left(R^{\star}, S^{*}\right)$-(-(4-hydroxyphenyl)- $(R)$-methyl-4-(phenyl-methyl)-1-piperidinepropranolol (Ro 25-6981 hydrochloride, 0.5 or $5 \mu \mathrm{M}$, as indicated in the text), as a GluN2B-selective antagonist; DL-2-amino-5phosphonovaleric acid (APV, $50 \mu \mathrm{M}$; Tocris Bioscience) as a subtype unselective antagonist of NMDA receptors; glutamic-pyruvic transaminase (GPT, $5 \mathrm{U} / \mathrm{ml}$ ), as glutamate scavenger, dialyzed against ACSF and coapplied with $2 \mathrm{~mm}$ pyruvate; PSA in the form of colominic acid sodium salt from Escherichia coli (10 $\mu \mathrm{M}$; Fluka); 4-(4-fluorophenyl)-2-(4methylsulfinylphenyl)-5-(4-pyridyl)-1H-imidazole (SB 203580, $10 \mu \mathrm{M}$ ); bicuculline methiodide $(20 \mu \mathrm{M})$, as antagonist of $\mathrm{GABA}_{\mathrm{A}}$ receptors; and (2S)-3-[[(1S)-1-(3,4-dichlorophenyl)ethyl] amino-2-hydroxypropyl] (phenylmethyl) phosphinic acid (CGP 55845, $10 \mu \mathrm{m}$; Tocris Bioscience), as antagonist of $\mathrm{GABA}_{\mathrm{B}}$ receptors. In all experiments with pharmacological rescue of LTP, the slices were perfused with a drug-containing ACSF immediately after a transfer to the recording chamber, i.e., $\sim 40 \mathrm{~min}$ before induction of LTP.

For isolation of the NMDA receptor-mediated component ([2] in Fig. $2 A$ ), the AMPA receptor-mediated fast component of the fEPSP [1], the amplitude of which was taken as $100 \%$, was blocked by perfusion with ACSF containing $0.25 \mathrm{~mm} \mathrm{Mg}^{2+}$, the AMPA/kainate receptor antagonist NBQX $(10 \mu \mathrm{M})$ and the $\mathrm{GABA}_{\mathrm{A}} /$ glycine receptor antagonist picrotoxin $(50 \mu \mathrm{M})$. Application of $0.25 \mu \mathrm{M}$ NVP or $5 \mu \mathrm{M}$ Ro 25-6981 isolated fEPSPs mediated predominantly by GluN2B- or GluN2A-containing receptors [3], respectively, which could be blocked to $1-1.5 \%$ level by the NMDA receptor antagonist APV $(50 \mu \mathrm{M})$ [4]. The ratio between amplitudes of NMDA and AMPA receptor-mediated components, was computed as $([2]-[4]) /([1]-[4])$, and the amplitude of NVP- or Ro 25-6981-insensitive component was computed as ([3] - [4])/([2] [4]), where numbers refer to the aforementioned components (shown for NVP-insensitive component in Fig. 2 A).

For statistical comparisons of LTP levels in different groups, measurements for these groups were performed in an interleaved manner and treated using ANOVA followed by multiple comparisons of groups with the post hoc Bonferroni $t$ test (SigmaStat, Systat Software Inc.). When raw data did not pass the normality test, ANOVA was performed on ranks.

Two-photon $\mathrm{Ca}^{2+}$ imaging. Hippocampal slices were obtained from 6to 7 -week-old Sprague Dawley rats. Slices were incubated for $2 \mathrm{~h}$ prior recording and then transferred to the recording chamber and superfused using a custom micro-perfusion system with a total volume of $2 \mathrm{ml}$ and a flow rate of $2-3 \mathrm{ml} / \mathrm{min}$. During recordings the slices were superfused with carbogenated $\mathrm{Mg}^{2+}$-free ACSF containing the following (in $\mathrm{mM}$ ): $120 \mathrm{NaCl}, 2.5 \mathrm{KCl}, 1 \mathrm{NaH}_{2} \mathrm{PO}_{4}, 26.2 \mathrm{NaHCO}_{3}, 2 \mathrm{CaCl}_{2}, 11$ glucose, 2

$\leftarrow$

$B$, The NMDA receptor-mediated component of fEPSP [1] is more strongly reduced by $5 \mu \mathrm{m}$ Ro 25-6981 [2] in $N C A M^{-/-}$mice than in $N C A M^{+/+}$mice. The inset shows representative traces corresponding to time intervals color-coded in $\boldsymbol{B}$. $\boldsymbol{C}$, The NMDA receptor-mediated component of fEPSP [1] is more strongly reduced by NVP in NCAM ${ }^{+/+}$mice [2], whereas $10 \mu \mathrm{M}$ PSA more strongly inhibits the residual component in NCAM ${ }^{-1-}$ mice [3]. The inset shows representative traces corresponding to time intervals color-coded in $\boldsymbol{C}$. B, C, Note that data show only NMDA receptor-mediated component of fEPSP after $60 \mathrm{~min}$ in the presence of NBQX, PiTX and $0.25 \mathrm{~mm} \mathrm{Mg}^{2+}$ and the amplitude of fEPSPs recorded $50-60 \mathrm{~min}$ in the presence of NBQX, PiTX and $0.25 \mathrm{~mm} \mathrm{Mg}^{2+}$ was taken as $100 \%$. The components left after APV application were subtracted for both genotypes. Bars represent means + SEMs of the amplitudes. Empty bars point to 10 min time intervals in which significant difference between genotypes was found, as indicated in the text. Numbers of recorded slices and mice, respectively, are indicated in parentheses. 
Na-pyruvate, and 0.25 4-methoxy-7-nitroindolinylglutamate (MNIGlu; Tocris Bioscience). AMPA and kainate receptors were blocked with $20 \mu \mathrm{M}$ CNQX (Tocris Bioscience); mGluR5 were blocked with $5 \mu \mathrm{M}$ Fenobam (Tocris Bioscience). Action potentials were blocked with $2 \mu \mathrm{M}$ tetrodotoxin. Whole-cell current-clamp recordings were made from CA1 pyramidal cells at room temperature $\left(23-24^{\circ} \mathrm{C}\right)$. The intracellular solution contained the following (in $\mathrm{mM}$ ): $120 \mathrm{~K}$-methanesulfonate, 10 HEPES, $4 \mathrm{MgCl}_{2}, 10 \mathrm{Na}$-phosphocreatine, $0.4 \mathrm{NaGTP}, 4 \mathrm{Na}_{2} \mathrm{ATP}, 0.1$ Alexa 594 (Invitrogen), 0.250 Fluo4 (Invitrogen). Recordings were discarded if the baseline Fluo4 fluorescence had changed $>25 \%$ or the membrane potential had changed $>5 \mathrm{mV}$ during the course of the experiment. Uncaging of MNI-Glu was done for $20 \mathrm{~ms}$ at a single spot with a $405 \mathrm{~nm}$ Laser (vortex mode of Olympus FV1000 Laser Scanning Microscope) at aspiny parts of dendrites to elicit an NMDA receptormediated response. $\mathrm{Ca}^{2+}$-dependent fluorescence of Fluo4 was measured with line-scan two-photon imaging (excitation at $810 \mathrm{~nm}$ ) before and after uncaging. Active or inactive forms of endoNF were applied to slices at a concentration of $576 \mu \mathrm{g} / \mathrm{ml}$ via pipettes with a diameter of tips $\sim 30 \mu \mathrm{m}$. In the series of experiments with the active form of endoNF, 2 $\mu \mathrm{g} / \mathrm{ml}$ colominic acid was sequentially added to the bath to inhibit responses potentiated by endoNF. At the end of each experiment, $10 \mu \mathrm{M}$ Co101244 (Tocris Bioscience), as selective GluN1/2B antagonist (Zhou et al., 1999; Kohl and Dannhardt, 2001), was applied, which largely blocked the response. Data are presented as mean \pm SEM and statistically evaluated using ANOVA with repeated measures and the post hoc Bonferroni $t$ test.

Analysis of $p 38$ and p42/p44 phosphorylation. Whole hippocampi were isolated from brains of adult mutants and control littermates for homogenization in ice-cold lysis buffer containing $10 \mathrm{~mm}$ Tris-Cl, pH 7.5, 150 mм NaCl, 1 mм EDTA, 1 mм Na-orthovanadate and 1 mm PMSF plus $1 \%$ NP-40, 0.1\% SDS and protease inhibitor cocktail (Roche Applied Science). This buffer was also used for homogenization of inactive and active endoNF-treated hippocampal slices (4 hippocampal slices from one mouse were pooled for one sample). Crude protein extracts were obtained by clearing the lysates by centrifugation at $13,000 \times g$ for $20 \mathrm{~min}$ at $4^{\circ} \mathrm{C}$. Proteins were subjected to SDS-PAGE and transferred onto nitrocellulose membrane (Protran, Schleicher \& Schuell). Following pretreatment in $5 \%$ nonfat dry milk powder in $0.1 \%$ Tween 20 in Trisbuffered saline, pH 7.5 (TBS), membranes were incubated in 5\% BSA in TBS containing anti-phospho-p38 (Thr180/Tyr182), anti-phosphop44/42 (Thr202/Tyr204) or anti-total p38 and anti-total p44/42 antibodies (1:1000; Cell Signaling Technology). After washing in 0.1\% Tween 20 in TBS, blots were incubated with horseradish peroxidase-conjugated secondary antibody $(1: 10,000)$. Blots were stripped and reblotted with GAPDH antibody as a loading control. Immunoreactivity was detected by enhanced chemiluminescence (ECL kit, GE Healthcare) on Kodak Biomax x-ray film (Sigma) according to the manufacturer's instructions. Band intensities were quantified by densitometry and normalized using intensities of $\mathrm{NCAM}^{+/+}$probes from the same blot (for $\mathrm{NCAM}^{-/-}$ hippocampi) or intensities of inactive endoNF-treated slices from the same mouse (for active endoNF-treated samples). Data are presented as mean \pm SEM and compared using ANOVA with repeated measures, followed by the post hoc Bonferroni $t$ test.

Fear conditioning. To assess both contextual and cued fear memories, an auditory fear conditioning paradigm was used (Senkov et al., 2006). Fear conditioning was performed as follows: (1) after $2 \mathrm{~d}$ of handling and habituation in a neutral context (home cage) for 5 min each day, the mouse was injected intrahippocampally with Ro 25-6981, or with vehicle as control, 15 min before training (Zhao et al., 2005); (2) subsequently, the mouse was placed into a conditioning chamber bearing conditioned context (CC+) and allowed to freely explore this context for $180 \mathrm{~s}$. Freezing levels during this time were taken as a baseline; (3) in a next step, the mouse was subjected to two pairings of $20 \mathrm{~s}$ episodes of conditioned stimulus $(\mathrm{CS}+$ ) presentation (delivered to half of the mice as a patterned tone, i.e., a series of 50 - $\mathrm{ms}-$ long $75 \mathrm{~dB}$ tones of $2.5 \mathrm{kHz}$ at $1 \mathrm{~Hz}$, and to the other half of the mice as a continuous tone of the same frequency) separated by $60 \mathrm{~s}$ and coterminated with a footshock as unconditioned stimulus (US); (4) $60 \mathrm{~s}$ after the last shock, the mouse was returned to its home cage (supplemental Fig. 2, available at www.jneurosci.org as supplemental material).

The following tests were performed on days 1 and 7 after induction of fear conditioning: (1) the mouse was placed into the conditioning chamber bearing context $\mathrm{CC}+$ used for fear conditioning for $3 \mathrm{~min}$ to assess its retention of contextual memory and then returned to its home cage; (2) after $\sim 2-3 \mathrm{~h}$ the same mouse was placed in a new neutral context (CC - ), a tone cage (see below), and was allowed to freely explore this context for $180 \mathrm{~s}$; in this way we could measure the level of generalization, as freezing in response to $\mathrm{CC}-$ and discrimination between $\mathrm{CC}+$ versus $\mathrm{CC}-$; (3) a $60 \mathrm{~s}$ episode of CS+ was presented (as patterned or continuous tone previously paired with a foot shock) to assess tone memory; $120 \mathrm{~s}$ later a $60 \mathrm{~s}$ presentation of unpaired CS - tone (either patterned or continuous, but different from CS+) was given; (4) $60 \mathrm{~s}$ after the last tone presentation the mouse was returned to its home cage.

Two fear conditioning chambers with two distinct CC + contexts were used for conditioning: an aluminum chamber which was cleaned before placing of a mouse with $75 \%$ ethanol, and a Plexiglas chamber which was cleaned with $1 \%$ acetic acid in water (supplemental Fig. 2, available at www.jneurosci.org as supplemental material). There were two tone cages bearing neutral CC - context: a tone cage with removable celled walls flavored with vanilla bakery oil, and another one containing removable circled walls flavored with lemon bakery oil, both cages were cleaned with water before placing of a mouse. One of two distinct CC+ and one of two distinct $\mathrm{CC}$ - were presented to the mouse to minimize dependency of results on a particular choice of $\mathrm{CC}+$ and $\mathrm{CC}-$. Patterned and continuous tones were used as CS + and CS - because mice had been observed to show a good discrimination between these tones in a fear conditioning paradigm (Tang et al., 2003; Senkov et al., 2006).

All experiments were performed in a double-walled soundattenuated isolation cubicle (for details, see Senkov et al., 2006). The unconditioned stimulus was a $1 \mathrm{~s}, 0.7 \mathrm{~mA}$ (AC) middle intensity shock delivered to the rod floor. Delivery of tones and shocks was controlled by customized software (Signal 1.88, CED, Cambridge, UK) using a Pentium-II computer through an AD/DA converter (Micro 1401 board, CED, Cambridge, UK).

Behavior of mice during conditioning and tests was recorded on a Pentium-4 computer, using a video frame-grabber (Pixelsmart, CA) which digitized the video streaming with 3 frames per second and stored it on the hard-drive as a set of 8-bit gray images. These images were then converted into "avi" format movies by the freely available Java-based program ImageJ (http://rsb.info.nih.gov/ij). All recorded movies were then analyzed using Microsoft Windows Media Player 9 by a trained observer blind to genotype and treatment of the respective mouse. Freezing time, as a measure of fear-related memory, was quantified as described previously (Tang et al., 2001). Briefly, freezing was detected if the animals remained motionless, except for respiratory movements, in a tense posture that was characterized by horizontal positioning of the head, a stretched state of the body and stiffening of the tail.

Data are expressed as mean \pm SEM. To analyze the effects of the injected compounds on contextual memory, we used ANOVA (Systat, Systat Software GmbH) having genotype and Ro 25-6981 treatment as between group factors, and day and context or tone as within group factors. ANOVA followed by the post hoc Bonferroni $t$ test if significant effects of factors were detected. Additionally, statistical comparison between freezing responses to CS + and CS - on a given day within each group was performed using the nonparametric Wilcoxon signed-rank test. Significant differences between groups were detected by the Wilcoxon test and the $t$ test for the same groups, and we therefore refer in the text only to $p$-values provided by the Wilcoxon test. Statistical significance of differences was accepted if $p<0.05$.

Surgical procedures. Chronic cannulation of mice was performed as described previously (Senkov et al., 2006). In brief, mice were anesthetized with a mixture of Ketamin and Rompun (Ketamin $100 \mathrm{mg} / \mathrm{kg}$, Rompun $16 \mathrm{mg} / \mathrm{kg}, 0.01 \mathrm{ml} / \mathrm{g}$ body weight, i.p.), placed in a stereotaxic frame (Narishige), their scalps were incised and retracted and two small holes were drilled. Bilaterally, sterile stainless steel 23 gauge double guide cannulas (Plastics One) were stereotaxically implanted reaching the border of the dorsal hippocampus under following coordinates (AP: $-2 \mathrm{~mm}$ 
and ML: $\pm 1.5 \mathrm{~mm}$ from the bregma; DV,-1.5 $\mathrm{mm}$ from the skull surface) according to Paxi$\operatorname{nos}(2001)$. For $N C A M^{-\prime-}$ mice, AP was -1.5 $\mathrm{mm}$, because their brain is shorter than normal due to abnormal development of olfactory bulbs and ventricles (Cremer et al., 1994). Guide cannulas were fixed on the skull bone by fast dental kallocryl cement (CPGM rot; Speiko). After the operation lasting for $\sim 30$ min, mice were placed back into their home cages and kept under a warm $\left(\sim 37^{\circ} \mathrm{C}\right)$ lamp until awakening. Metamizol $(50 \mathrm{mg} / \mathrm{kg}$ body weight, i.p.) was used as a postoperative analgesic. The following behavioral investigations were performed after the mice had fully recovered 5-7 d after surgery.

Drugs for behavioral studies. To test whether the block of GluN2B-containing receptors in the hippocampus would improve learning in $N C A M^{-1-}$ mice, we used the GluN2B selective antagonist Ro 25-6981 at a concentration of $20 \mu \mathrm{g} / \mu \mathrm{l}(0.5 \mu \mathrm{l} / \mathrm{site} / \mathrm{min})$, which is close to the concentration previously used for injection into the hippocampus and shown to be ineffective in fear conditioning in wild-type mice (Zhao et al., 2005). The bilateral injection cannulas (\#C235, Plastics One) were connected to a pump (TSE Systems) through a Tygon tubing system. The injection cannulas were gently inserted into the bilateral guide cannulas $\sim 10 \mathrm{~s}$ before injection, extending the tips of the guide cannulas by $1 \mathrm{~mm}$. The site of the injection was aimed to the hilus of the left and right hippocampi. The injection cannulas were left within the guide cannulas for at least $60 \mathrm{~s}$ after injection.

Since fear conditioning is sensitive to stress, especially when it occurs before training, special care was taken to minimize stress during i.p. or intrahippocampal injection procedures. To this end, all mice were slightly sedated with a mixture of $\mathrm{CO}_{2}$ and room air for the period of injection, i.e., approximately for 2 min. Recovery after anesthesia was fast (2-3 $\mathrm{min}$ ) and without any side effects in the following fear conditioning experiments (Senkov et al., 2006).

Histology. To verify the injection sites, brains were investigated histologically after the behavioral tests. Mice were reinjected with solution containing the dye methylene blue, using the same injection procedure as used for injection of Ro 25-6981. Fifteen minutes after this reinjection the mice were deeply anesthetized with pentobarbital (100 mg/kg body weight) and transcardially perfused with $4 \%$ paraformaldehyde in PBS, pH 7.4, during 20 min. Brains were postfixed overnight in the same fixative at $4^{\circ} \mathrm{C}$. The brains were then cut into $100 \mu \mathrm{m}$ thin slices near the injecting area. Slices were then inspected microscopically and photographed.

\section{Results}

\section{PSA inhibits GluN1/2B and GluN1/2A/2B receptors}

Our previous pharmacological study revealed that PSA inhibits GluN2B-containing receptors in primary hippocampal cultures (Hammond et al., 2006). In the mature hippocampus, NMDA receptors predominantly have the following composition: GluN1/2A, GluN1/2B and GluN1/2A/2B (Köhr, 2006). To identify which of these NMDA receptor subtypes are inhibited by PSA, we transfected Chinese hamster ovary cells with these three
B

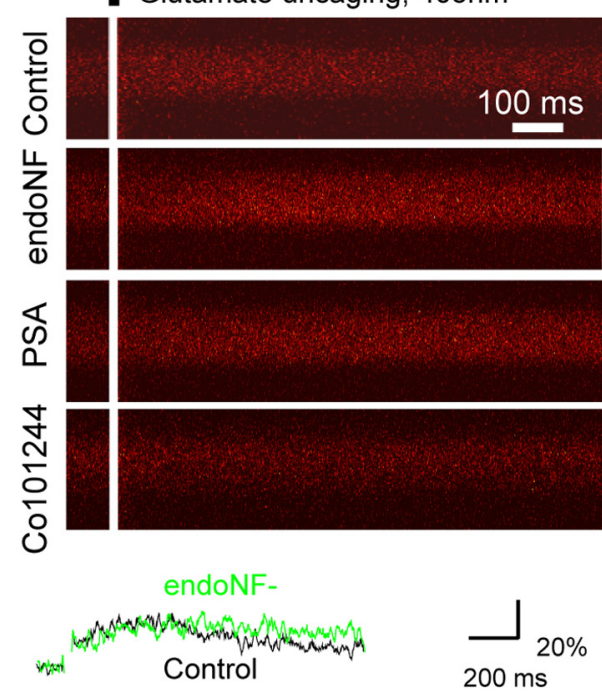

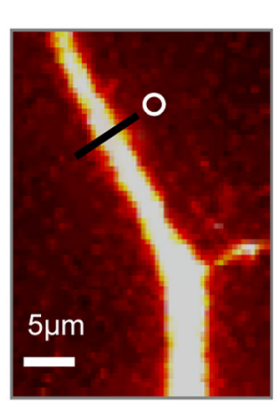

250

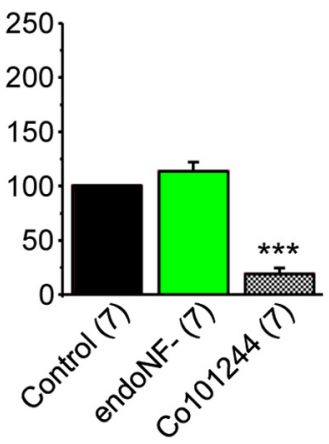

Figure 3. Acute removal of PSA upregulates GluN2B-mediated $\mathrm{Ca}^{2+}$ transients in CA1 pyramidal cells. $A$, Left: CA1 pyramidal neuron filled with $250 \mu \mathrm{m}$ Flu04. The sample image was obtained with high laser power to reveal the morphology of the cell. The ashed rectangle indicates the area of recording which is shown enlarged in the right image. The black line shows the line scan The white vertical line indicates the time of glutamate uncaging. Upper and bottom show the $\mathrm{Ca}^{2+}$ signal in control conditions (Control), after active endoNF application (endoNF), PSA application (PSA) and application of the GluN2B-specific antagonist (r) traces from twe neurons. Left: three sweeps showing $\mathrm{Ca}^{2+}$ transients in response to glutamate transients recorded in another slice in the control condition and after inactive endoNF (endoNF-) application. D, Mean + SEM of measurements obtained in the experiments with application of active and inactive forms of endoNF (left and right panels, respectively). The active form of endoNF increased the integral of the $\mathrm{Ca}^{2+}$ signal more than twice. Two-way ANOVA with repeated measures revealed the effect of treatments on the integral of $\mathrm{Ca}^{2+}$ transients $(p<0.001)$. Comparisons with controls revealed the effects of endoNF and C0101244: ${ }^{*} p<0.05,{ }^{* *} p<0.01,{ }^{* *} p<0.001 ;{ }^{+} p<0.05$, significant difference between endoNFand PSA-treated groups, post hoc Bonferroni $t$ test; numbers of recorded cells are indicated in parentheses.

combinations of GluN subunits, prepared membranes from transfected cells, fused these with lipid bilayer membranes formed at the tip of patch pipette and compared activities of reconstituted NMDA receptors in the absence and presence of PSA. Single-channel activity was detected by an upward transition of the current, which represented the open state (Fig. 1A-C). The mean values of open probability and conductance of recorded channels are shown in Figure $1 D$. GluN1/2A/2B were identified by their low sensitivity to antagonists of GluN1/2A (50 $\mathrm{nM} \mathrm{ZnCl}_{2}$ ) and GluN1/2B receptors (0.25 $\mu \mathrm{M}$ Ro 25-6981). Single-channel activities elicited by glutamate in GluN1/2B (Fig. $1 A$ ) and GluN1/2A/2B (Fig. $1 C$ ) receptors were sensitive to PSA. In contrast, addition of PSA had no significant effect on GluN1/2A receptors (Fig. $1 B$ ). Statistical evaluation revealed a progressive decrease in the open channel probability of GluN1/2B and GluN1/2A/2B receptors when the PSA concentra- 

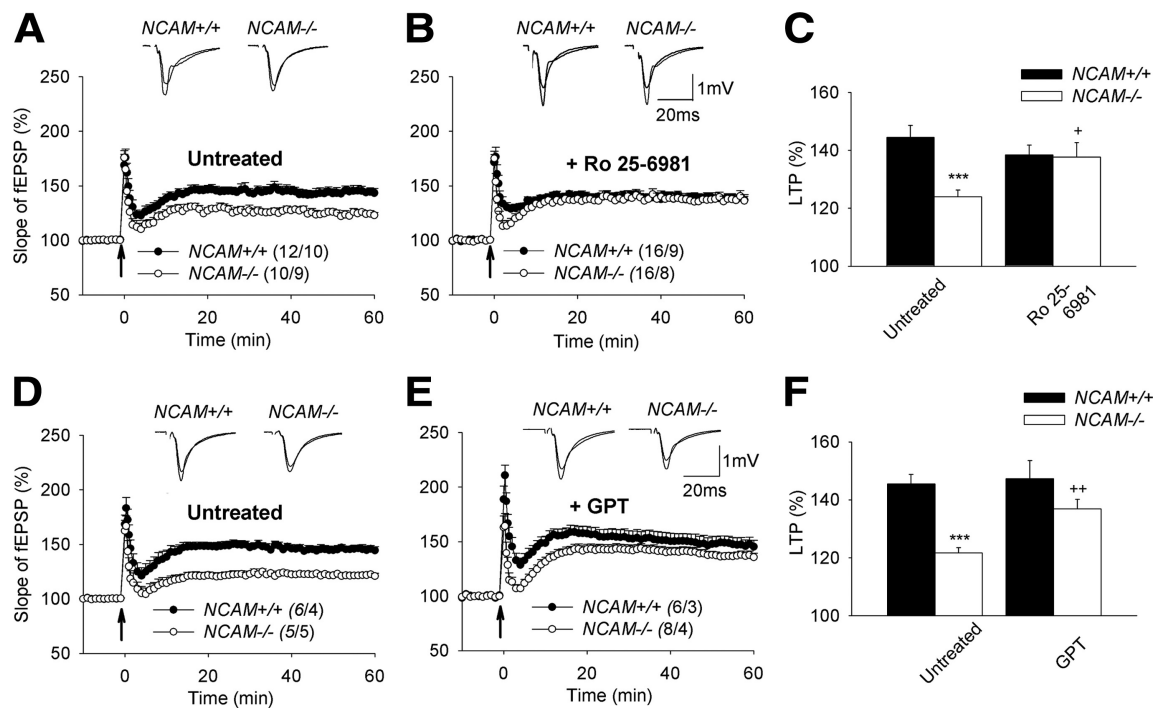

Figure 4. Restoration of impaired LTP in NCAM ${ }^{-1-}$ mice through inhibition of GluN2B-containing receptors. Restoration of impaired LTP in NCAM ${ }^{-/-}$mice $(\boldsymbol{A}, \boldsymbol{D})$ by application of the GluN2B-selective antagonist Ro 25-6981 (B), or the glutamate scavenger GPT $(\boldsymbol{E})$. The mean slope of fEPSPs recorded $10 \mathrm{~min}$ before TBS was taken as $100 \%$ and arrows indicate delivery of TBS. Data represent mean + SEM, numbers of tested slices and mice, respectively, are indicated in parentheses. Insets show averages of 30 fEPSPs recorded 10 min before and 50-60 min after TBS. C, $\boldsymbol{F}$, Mean + SEM of LTP levels recorded 50-60 min after TBS. Tw0-way ANOVA revealed the effect of NCAM ( $p<0.001)$, and interaction between NCAM and Ro 25-6981 treatment $(p<0.05)$ in Cand the effect of NCAM $(p<0.001)$, GPT treatment $(p<0.05)$ and interaction between NCAM and GPT $(p<0.05)$ in $\boldsymbol{F} .^{* * *} p<0.001$, significant difference between NCAM ${ }^{+/+}$and NCAM ${ }^{-/-}$mice; ${ }^{+} p<0.05,{ }^{++} p<0.01$, significant difference between untreated control and pharmacologically treated mice of the same genotype, post hoc Bonferroni $t$ test.

tion was increased from 1 to 2 and $3 \mu \mathrm{g} / \mathrm{ml}$, without changes in single-channel conductance (Fig. $1 E$ ). After addition of 1,2 , and $3 \mu \mathrm{g} / \mathrm{ml}$ PSA, the open probability of GluN1/2B receptors decreased to $72.7 \pm 1.1,50.6 \pm 1.1,21.6 \pm 0.7 \%$ of control levels, respectively (Fig. $1 E$ ). The open probability of GluN1/2A/2B receptors decreased after addition of 1,2 , and $3 \mu \mathrm{g} / \mathrm{ml}$ PSA to $73.8 \pm 4.9,59.4 \pm 6.8,33.4 \pm 4.1 \%$, respectively (Fig. $1 E$ ). ANOVA revealed that the inhibition by PSA was stronger for GluN1/2B than for GluN1/2A/2B receptors. Neither the open probability nor conductance of GluN1/2A receptors was affected by 1, 2, 3 and even by $10 \mu \mathrm{g} / \mathrm{ml}$ PSA (Fig. $1 E$ ). These data demonstrate that PSA selectively inhibits diheteromeric GluN1/2B and triheteromeric GluN1/2A/2B receptors.

\section{$N C A M^{-1-}$ mice have increased GluN2B-mediated transmission in hippocampal CA3-CA1 synapses}

Data from single-channel recordings suggests that the GluN2Bmediated component of synaptic transmission might be larger in NCAM-deficient $\left(N C A M^{-/-}\right)$mice compared with wild-type control littermates $\left(N C A M^{+/+}\right.$mice). We tested this hypothesis in hippocampal slices. The ratio between amplitudes of NMDA and AMPA receptor-mediated responses was not different between genotypes: $9.7 \pm 1.7 \%$ in $\mathrm{NCAM}^{-/-}$mice versus $9.3 \pm$ $0.5 \%$ in $\mathrm{NCAM}^{+/+}$mice (Fig. $2 \mathrm{~A}$ ). Also, the basal AMPA receptor-mediated synaptic transmission and its paired-pulse modulation were normal in $N C A M^{-/-}$mice (supplemental Fig. 3, available at www.jneurosci.org as supplemental material). To isolate the GluN2B-mediated component of postsynaptic responses, we used the NMDA receptor antagonist NVP at a concentration of $0.25 \mu \mathrm{M}$ that inhibits $\sim 80 \%$ of currents mediated by GluN1/2A receptors and only $\sim 20 \%$ of currents mediated by GluN1/2B receptors (Bartlett et al., 2007). The amplitude of this component was larger in $N C A M^{-/-}$mice $(35.7 \pm 4.9 \%)$ than in
$N C A M^{+/+}$mice $(22.0 \pm 1.3 \%)(p<0.05$, $t$ test). Complementary experiments with evaluation of the component insensitive to the GluN2B-specific antagonist Ro 25$6981(5 \mu \mathrm{M})$ revealed a reduction of this presumably GluN2A-mediated component in $N C A M^{-1-}$ mice $(64.0 \pm 2.3 \%)$ compared with $\mathrm{NCAM}^{+/+}$mice $(74.8 \pm$ $1.4 \%)(p<0.01, t$ test $)$. A sum of NVPand Ro 25-6981-insensitive responses was on average $97 \%$ and $100 \%$ of total NMDA receptor-mediated response for $\mathrm{NCAM}^{+/+}$and $\mathrm{NCAM}^{-/-}$mice, respectively. These data underline the validity of the procedure used here for dissection of GluN2A- and GluN2B-mediated components.

To test whether an increase in the GluN2B-mediated component reflects a deficit in inhibition of GluN2B-containing receptors by PSA in $N C A M^{-/-}$ mice, we applied PSA to hippocampal slices and found that it inhibited the NVPinsensitive component more strongly in $\mathrm{NCAM}^{-/-}$than in $\mathrm{NCAM}^{+/+}$mice $(20.1 \pm 2.5 \%$ vs $12.0 \pm 1.7 \%$, respectively; $p<0.05$, $t$ test) (Fig. 2C). Together, these observations suggest that despite normal total NMDA receptor-mediated transmission in $N C A M^{-/-}$mice, there is an increase in transmission via GluN2B.

\section{Acute removal of PSA upregulates GluN2B-mediated} $\mathrm{Ca}^{2+}$ transients in CA1 pyramidal cells

To further investigate whether a deficit of PSA in hippocampal slices would increase GluN2B-mediated $\mathrm{Ca}^{2+}$ influx, we performed recordings of $\mathrm{Ca}^{2+}$ transients in the aspiny, presumably extrasynaptic, part of CA1 apical dendrites (Fig. $3 A$ ) before and after application of the specifically PSA-digesting enzyme endosialidase NF (endoNF) (Stummeyer et al., 2005). As control, we used slices treated with an endoNF inactivated by point mutations in the active site (Stummeyer et al., 2005). $\mathrm{Ca}^{2+}$ influx was elicited by local uncaging of glutamate and recorded using the $\mathrm{Ca}^{2+}$-sensitive dye Fluo4 (Fig. 3 B, C). Treatment with endoNF increased the integral of recorded $\mathrm{Ca}^{2+}$ signals to $209 \pm 31 \%$ relatively to the signals recorded before treatment. In line with findings that PSA suppresses the opening of GluN2B-containing receptors only at low micromolar glutamate concentrations (Hammond et al., 2006), the difference between $\mathrm{Ca}^{2+}$ transients recorded in control and endoNF-treated cells was observed during the late phase of transients, i.e., when concentration of uncaged glutamate was low. PSA applied after endoNF treatment largely reversed the increase of the $\mathrm{Ca}^{2+}$ signal $(137 \pm 9 \%$ of signal before endoNF treatment) (Fig. $3 B-D$ ). Further application of Co101244, a selective GluN2B antagonist (Zhou et al., 1999 ), reduced the $\mathrm{Ca}^{2+}$ signals to $23 \pm 6 \%$, showing that they were predominantly mediated by GluN2B (Fig. $3 B, D$ ). Inactive endoNF did not significantly change the integral of $\mathrm{Ca}^{2+}$ signals $(113 \pm 8 \%)$, whereas further application of Co101244 reduced the responses to $19 \pm 5 \%$ (Fig. $3 B, D$ ). These experiments directly visualize the acute upregulation of GluN2B-mediated $\mathrm{Ca}^{2+}$ transients in CA1 pyramidal cells after removal of PSA. 


\section{Impaired LTP in NCAM/PSA-deficient hippocampus can be restored via inhibition of GluN2B-containing receptors}

Analysis of synaptic plasticity induced by theta-burst stimulation of Schaffer collaterals/commissural fibers revealed an impairment of LTP in CA1 of $N_{C A M}{ }^{-\prime-}$ mice $(123.9 \pm 2.3 \%)$ compared with $\mathrm{NCAM}^{+/+}$mice $(144.4 \pm 4.1 \%)$ (Fig. $4 A, C)$. Since our data demonstrate an increase in GluN2B-mediated transmission in $\mathrm{NCAM}^{-1-}$ mice (Fig. 2) and since activation of GluN2B-containing receptors might promote synaptic depression (Massey et al., 2004), we next tested whether inhibition of GluN2B would normalize LTP in $N C A M^{-1-}$ mice. Indeed, application of the GluN2B-selective antagonist Ro 25-6981 (0.5 $\mu \mathrm{M})$ increased LTP in $N C A M^{-/-}$mice to $137.6 \pm 4.9 \%$, a value not significantly different from the level of $138.4 \pm 3.3 \%$ recorded in parallel (i.e., in an interleaved manner) in $\mathrm{NCAM}^{+/+}$mice (Fig. $4 B, C$ ). We next recorded LTP in the presence of a glutamate scavenger GPT, a substance known to substantially reduce concentrations of extrasynaptic glutamate (Tsvetkov et al., 2004) and, thus, to reduce activity of GluN2Bcontaining receptors. This treatment also increased LTP in $\mathrm{NCAM}^{-/-}$mice to $136.8 \pm 3.2 \%$, being not significantly different from the level of $147.3 \pm 6.2 \%$ found in parallel recordings in $\mathrm{NCAM}^{+/+}$ mice (Fig. $4 D-F$ ). Thus, LTP in NCAM ${ }^{-/-}$ mice can be fully restored by treatments that decrease transmission via GluN2B or reduce extrasynaptic glutamate concentration.

Similarly to ablation of NCAM, removal of PSA with recombinant endoNF (supplemental Fig. 1, available at www.jneurosci. org as supplemental material) impaired LTP (Fig. 5A,C), as previously reported for another preparation of endosialidase $\mathrm{N}$ (Becker et al., 1996; Muller et al., 1996). As a negative control, we show that inactive endoNF did not inhibit LTP and was not different from sham controls (Fig. 5A,C). Blockade of GluN2B with Ro 25-6981 (Fig. 5A,C) increased levels of LTP in endoNFtreated slices to levels not different from those observed after treatment with inactive endoNF or in sham controls (Fig. $5 \mathrm{~A}, \mathrm{C}$ ). Thus, these data replicate results from the experiments in $N C A M^{-1-}$ mice and demonstrate that impaired LTP in either NCAM- or PSA-deficient slices is due to improper signaling via GluN2B.

One possible explanation for our results would be that elevated signaling via GluN2B expressed by interneurons in NCAM/ PSA-deficient mice facilitates activation of interneurons and hence impairs LTP via enhanced activation of $\mathrm{GABA}_{\mathrm{A}} / \mathrm{GABA}_{\mathrm{B}}$ receptors. Although normal amplitudes of unitary IPSCs were reported in hippocampal cultures of $\mathrm{NCAM}^{-1-}$ neurons (Dityatev et al., 2000), no information is available regarding recruitment of interneurons during TBS in NCAM/PSA-deficient slices. Here, we investigated this issue by recording LTP in the presence of $\mathrm{GABA}_{\mathrm{A}}$ and $\mathrm{GABA}_{\mathrm{B}}$ receptor inhibitors, bicuculline and CGP 55845, in endoNF-treated slices. As the difference between endoNF-treated and control slices remained $\sim 20 \%$ after blockade of GABAergic inhibition (Fig. $5 B, C$ ), we conclude that it is unlikely that modulation of GABAergic inhibition mediates the effects of PSA on LTP.

\section{Inhibition of enhanced p38 MAPK activity in NCAM/PSA-deficient hippocampus normalizes impaired LTP}

As GluN2B-containing receptors are involved in both potentiation and depression of synaptic transmission (Tang et al., 1999; Massey et al., 2004), a critical question pertains to the downstream signaling mechanisms of PSA-dependent GluN2Bcontaining receptors. Previous reports highlighted p38 mitogenactivated protein kinase (MAPK) as a key player in synaptic depression (Bolshakov et al., 2000; Hsieh et al., 2006). We therefore investigated the levels of active MAPKs in the hippocampus of $N C A M^{-1-}$ mice and found an almost fourfold upregulation of p38 MAPK phosphorylation (Fig. 6A,B) and a twofold increase in phosphorylated p44 (Fig. $6 A, B$ ), whereas phosphorylation of p42 (Fig. $6 A, B$ ) and protein levels of p38, p42 and p44 (supplemental Fig. 4, available at www.jneurosci.org as supplemental material) were not changed. The level of phosphorylated p38 was also upregulated in active endoNF- compared with inactive endoNF-treated hippocampal slices (Fig. 6A,C), without changes in the protein level (supplemental Fig. 4, available at 


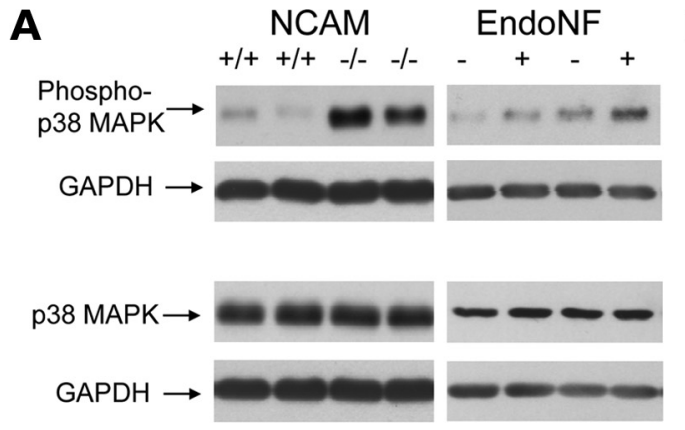

B

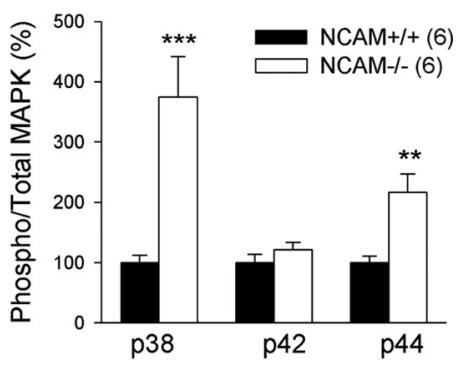

C
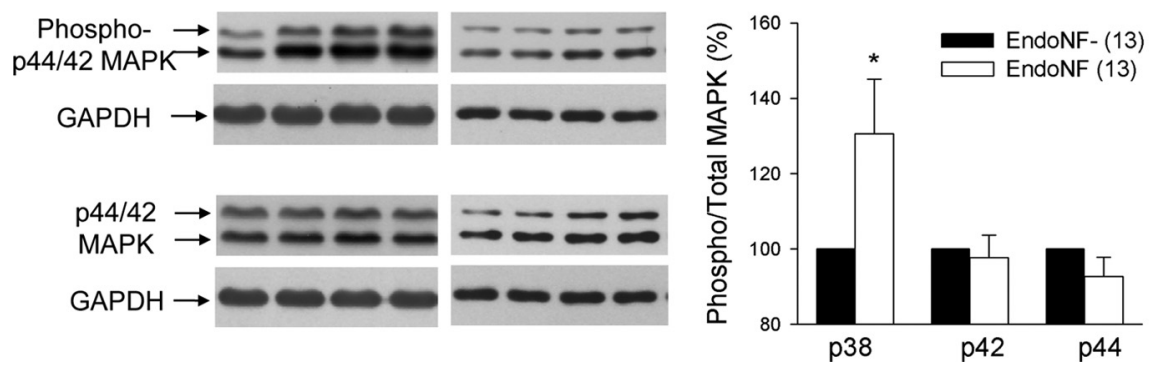

Figure 6. Elevated signaling via p38 MAPK in NCAM ${ }^{-/-}$mice and endoNF-treated slices. $\boldsymbol{A}$, Western blots showing levels of phosphorylated (phospho) and total p38 and p42/p44 MAPK proteins in the hippocampi of NCAM ${ }^{+/+}$versus NCAM ${ }^{-/-}$mice, and in active $(+)$ versus inactive $(-)$ endoNF-treated slices. Blots were stripped and reblotted with GAPDH antibody as a loading control. The intensity of GAPDH signal was used for normalization of corresponding MAPK signals. $\boldsymbol{B}$, Mean + SEM of the levels of phosphorylated p38, p42 and p44 MAPKs in NCAM ${ }^{+/+}$versus NCAM ${ }^{-/-}$hippocampi. Band intensities for NCAM ${ }^{-/-}$and $N C A M^{+/+}$probes from the same blot were normalized using an average intensity of $N C A M^{+/+}$probes. Two-way ANOVA with repeated measures revealed the effects of NCAM $(p<0.01)$, MAPK identity $(p<0.001)$, and interaction between NCAM and MAPK $(p<0.001) .{ }^{* *} p<0.001,{ }^{* *} p<0.01$, significant difference between genotypes, post hoc Bonferroni $t$ test. C, Mean + SEM of the levels of phosphorylated p38, p42 and p44 in inactive (endoNF-) and active endoNF-treated hippocampal slices. Each band intensity corresponding to active endoNF-treated slices derived from one mouse was normalized using the band intensity corresponding to inactive endoNF-treated slices from the same mouse (set to 100\%), with both bands being from the same blot. Two-way ANOVA with repeated measures revealed the effect of MAPK identity $(p<0.01)$ and interaction between MAPK and endoNF treatment $(p<0.01) .{ }^{*} p<0.05$, significant difference between slices treated with active and inactive endoNF, post hoc Bonferroni $t$ test.

www.jneurosci.org as supplemental material). Upregulation of p38 phosphorylation in endoNF-treated slices was, however, lower than in $\mathrm{NCAM}^{-1-}$ mice. This can be due to an increase in phosphorylated p38 in control slices during dissection of slices and/or due to low levels of basal spontaneous neuronal activity in acute slices (compared with intact brains), which would reduce the level of GluN2B and, hence, p38 activation in endoNF-treated slices. Still, during induction of LTP, the GluN2B-p38 pathway might be activated in endoNF-treated as well as in $N C A M^{-1-}$ slices by theta-burst stimulation-evoked glutamate release.

Indeed, inhibition of p38 MAPK activity with SB 203580 restored LTP in $N C A M^{-1-}$ mice to $137.2 \pm 6.1 \%$ (Fig. $7 A-C$ ). Also, LTP was restored to normal levels by addition of SB 203580 to endoNF-treated slices (to $133.5 \pm 3.7 \%$ ) (Fig. $7 D, E, G)$. SB 203580 had no effect on LTP in slices of wild-type mice (Fig. $7 C, G$ ).

\section{Enhanced GluN2B-mediated activation of p38 MAPK via Ras-GRF1 results in reduction of LTP in NCAM/PSA-deficient hippocampus}

The $\mathrm{Ca}^{2+}$-dependent Ras-guanine releasing factor (GRF) 1 may mediate activation of p38 MAPK by GluN2B-containing receptors (Li et al., 2006). We therefore studied LTP in mice deficient in Ras-GRF1. In contrast to wild-type mice (Fig. 7D), enzymatic removal of PSA in this mutant did not impair LTP (135.3 $\pm 2.9 \%$ in sham vs $133.3 \pm 2.5 \%$ in endoNF-treated mutants) (Fig.
$7 F, G)$, suggesting that enhanced GluN2Bmediated activation of p38 MAPK via RasGRF1 accounts for reduction of LTP in the absence of NCAM/PSA.

\section{Impaired contextual fear conditioning in $N C A M^{-1-}$ mice can be rescued via suppression of intrahippocampal GluN2B-containing receptors}

$N C A M^{-1-}$ mice are impaired in contextual and cued (tone) memories in fear conditioning paradigms (Stork et al., 2000; Senkov et al., 2006). To verify the hypothesis that this deficit in hippocampus-dependent contextual learning is related to increased activity of GluN2B-containing receptors, we attempted to rescue learning deficits by injection of Ro 25-6981 into the hippocampi of $N C A M^{-1-}$ and $N C A M^{+/+}$ mice $15 \mathrm{~min}$ before training and assessed its effects on contextual and cued fear memories on the first and seventh test days (Fig. 8A). Intrahippocampal injection was necessary in these experiments to exclude inhibition of GluN2B-containing receptors that are required for fear conditioning-associated neuroplasticity outside the hippocampus, for instance in the amygdala and prefrontal cortex (Rodrigues et al., 2001; Zhao et al., 2005). $N C A M^{-1-}$ mice injected with vehicle showed a twofold decrease in contextual memory compared with vehicle-injected $N_{C A M}{ }^{+/+}$mice at every test day (Fig. $8 B$ ). This robust learning deficit was fully rescued by intrahippocampal injection of Ro 25-6981, which normalized not only short- and long-term contextual memory, but also the animals' ability to discriminate between conditioned and neutral contexts (Fig. $8 B$ ). In contrast, cued memory in $N C A M^{-/-}$mice was not improved by injection of Ro 25-6981 (Fig. 8 B), although discrimination of tones was significantly facilitated on the seventh test day (Fig. 8 B). In $N C A M^{+/+}$mice, injection of Ro 25-6981 had no significant effect on discrimination of contexts, although it had a tendency to reduce discrimination of tones.

\section{Discussion}

The present study provides evidence that PSA-NCAM restrains signaling via a subset of GluN2B-containing receptors. Our working model linking this phenomenon to a reduction in LTP can be summarized as follows: In wild-type animals, NCAMassociated PSA inhibits activation of GluN2B-containing receptors (Hammond et al., 2006), possibly by steric hindrance of the ligand to access the glutamate binding site. Importantly, this inhibition occurs only at low micromolar concentrations of glutamate (Hammond et al., 2006). In the absence of NCAM or PSA, GluN2B-mediated activity at low concentrations of glutamate becomes more prominent and results in activation of p 38 MAPK, which together with reduced signaling via GluN2A-containing receptors impairs LTP (supplemental Fig. 5, available at www. jneurosci.org as supplemental material). Thus, in addition to the well recognized anti-adhesive property of PSA, being critically important for modulation of cell interactions during develop- 
ment (Rutishauser, 2008), PSA regulates synaptic plasticity in adulthood via modulation of a specific population of glutamate receptors. PSA inhibits GluN2Bcontaining receptors at low micromolar concentrations of glutamate found in the extracellular space (Sherwin, 1999; Ueda et al., 2000), which are two orders of magnitude below glutamate concentrations in the synaptic cleft after vesicular glutamate release. Thus, it is plausible to expect that although PSA may act on both synaptic and extrasynaptic GluN2B receptors, it would effectively inhibit transmission preferentially via extrasynaptic GluN2B receptors. The influence of PSA on GluN2B at stimulated synapses would be negligible since glutamate is released at high concentrations and then PSA is not effective. As GluN2B-containing NMDA receptors can signal via multiple intracellular pathways (for review, see Ponimaskin et al., 2007), synaptically and extrasynaptically, they may influence LTP positively or negatively depending on the balance between these pathways. For instance, during early development and in mice overexpressing GluN2B (Tang et al., 1999; Köhr et al., 2003) the balance is shifted toward synaptic (rather than extrasynaptic) signaling that promotes LTP. However, manipulations leading to lateral movement of synaptic GluN2B to extrasynaptic sites (reduction of either CaMKII/GluN2B or PSD-95/GluN2B association) result in impairment of LTP (Gardoni et al., 2009). Also in hippocampal slices from adult NCAM/ PSA-deficient mice, the balance between synaptic and extrasynaptic pathways seems to shift in favor of GluN2B-mediated extrasynaptic signaling and activation of p38 MAPK, as discussed below.

Although one should be cautious with interpretation of pharmacological data regarding the function of extrasynaptic NMDA receptors (Neyton and Paoletti, 2006), it is noteworthy that several lines of evidence point to an increase in extrasynaptic GluN2B-mediated signaling in NCAM/PSA-deficient slices and its importance for modulation of LTP: (1) PSA suppresses opening of native ifenprodil/Ro 25-6981-sensitive receptors by low concentrations of glutamate (Hammond et al., 2006). (2) PSA suppresses the activity of recombinantly expressed GluN1/2B and GluN1/2A/2B, but not GluN1/2A receptors. (3) In hippocampal slices of $\mathrm{NCAM}^{-/-}$mice, the NVP-insensitive component is larger and is more strongly inhibited by PSA than in slices from $\mathrm{NCAM}^{+/+}$mice. (4) Ro 25-6981-sensitive component is enlarged in slices from $N C A M^{-1-}$ mice. (5) Removal of PSA increases GluN2B-mediated $\mathrm{Ca}^{2+}$ transients in the aspiny part of dendrites. (6) Inhibition of GluN2B-containing receptors with Ro 25-6981 restores levels of LTP in NCAM- or PSAdeficient slices to the levels seen in slices from wild-type mice. (7) Mice deficient in the glial glutamate transporter GLT-1 have an increased extracellular concentration of glutamate and impaired LTP (Katagiri et al., 2001). (8) Reduction of extrasynaptic glutamate concentrations by the glutamate scavenger GTP restores
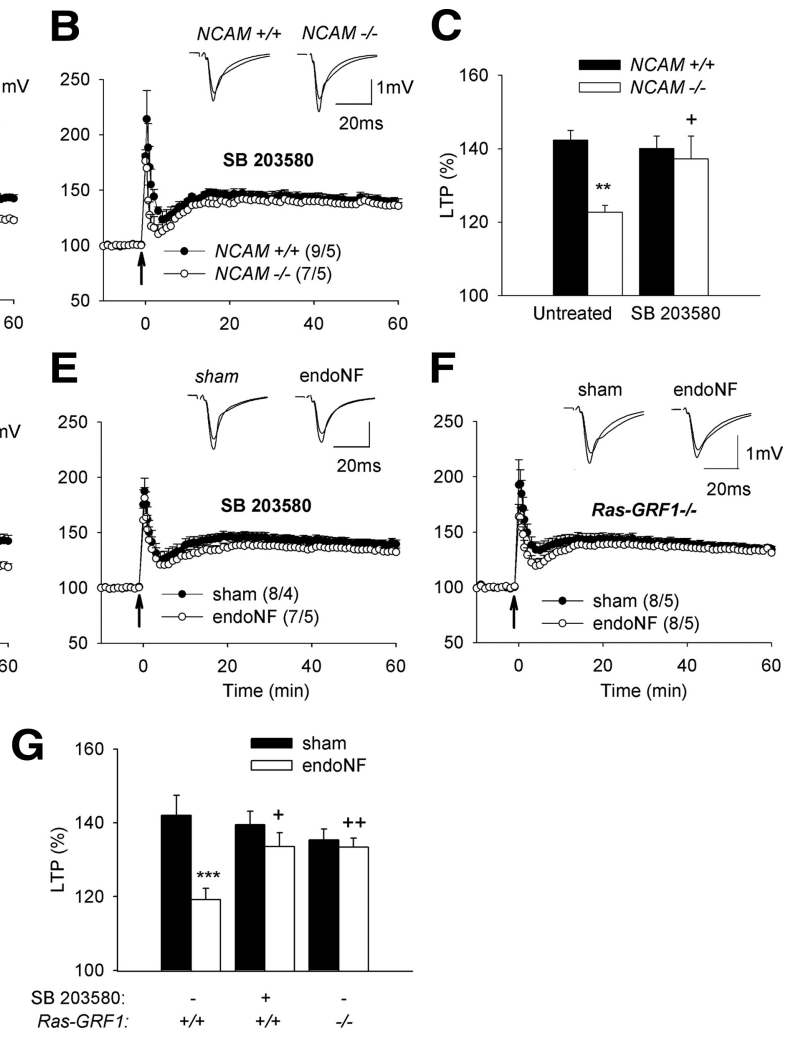

$\begin{array}{cccc}\text { SB 203580: } & - & + & - \\ \text { Ras-GRF1: } & +/+ & +/+ & -\end{array}$

Figure 7. Restoration of impaired LTP in NCAM ${ }^{-1-}$ and/or EndoNF-treated hippocampal slices via inhibition of $\mathrm{p} 38$ or ablation of Ras-GRF1. Application of the p38 inhibitor, SB $203580(\boldsymbol{B})$, restores impaired LTP in slices from NCAM ${ }^{-1-}$ mice $(\boldsymbol{A})$ to the levels parentheses. Insets show averages of 30 fEPSPs recorded 10 min before and $50-60$ min after TBS. C, G Mean + SEM of LTP Ievels recorded $50-60$ min after TBS. Two-way ANOVA revealed the effect of NCAM $(p<0.01)$ and interaction between NCAM and SB (treatment $(p<0.05)$ in $C$ and the effect of endoNF $(p<0.001)$ and interactions between endoNF and SB 203580 slices from $N_{C A M}{ }^{+/+}$versus $N C A M^{-/-}$mice or between sham versus endoNF-treated slices, ${ }^{++} p<0.01,{ }^{+} p<0.05$ significant effects of SB 203580 or Ras-GRF1 ablation, post hoc Bonferroni $t$ test.

LTP in NCAM ${ }^{-/-}$mice. (9) A substantial fraction of GluN2Bcontaining receptors is located extrasynaptically in the adult hippocampus (for review, see Köhr, 2006). (10) The synaptic pool of NMDA receptors activates the extracellular signal-regulated kinases, whereas the extrasynaptic pool triggers a signaling cascade that results in the inactivation of this pathway (Ivanov et al., 2006).

Interestingly, at $22-24^{\circ} \mathrm{C}$ the extrasynaptic signaling in response to a single electrical pulse is exaggerated compared with $35-37^{\circ} \mathrm{C}$ (Asztely et al., 1997). The recording at temperatures of $22-24^{\circ} \mathrm{C}$ was thus instrumental in our in vitro measurements for a better detection of differences between NCAM genotypes in terms of GluN2B-mediated signal and its inhibition by PSA (Fig. 2). However, in response to short trains of stimuli or theta-burst stimulation, extrasynaptic receptors are activated at both $22-24^{\circ} \mathrm{C}$ and $35-37^{\circ} \mathrm{C}$ (Asztely et al., 1997). In line with this data, it has been shown that slices from $N C A M^{-1-}$ mice and endoN-treated slices at $35-37^{\circ} \mathrm{C}$ (Muller et al., 1996) were similarly impaired in LTP as in our present and several previous studies conducted at room temperature. Furthermore, our behavioral experiments with intrahippocampal inhibition of GluN2B support the view that the revealed mechanism is valid at physiological conditions in vivo.

The following data support the view that the mechanisms downstream of GluN2B-containing receptors in NCAM/PSA- 
A

Intrahippocampal Injection
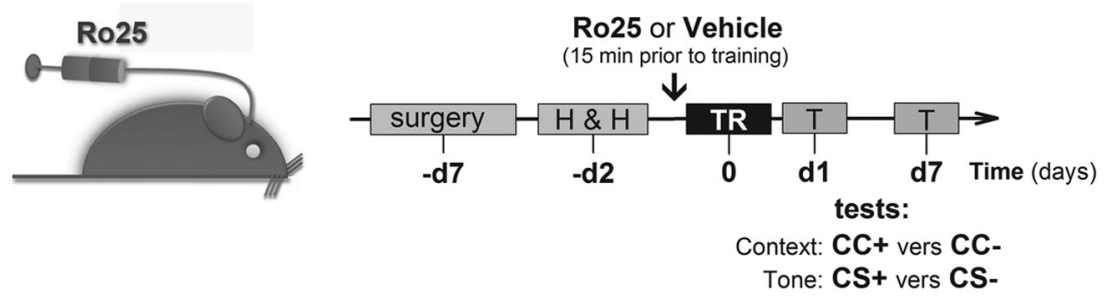

B

Contextual Memory

Tone Memory
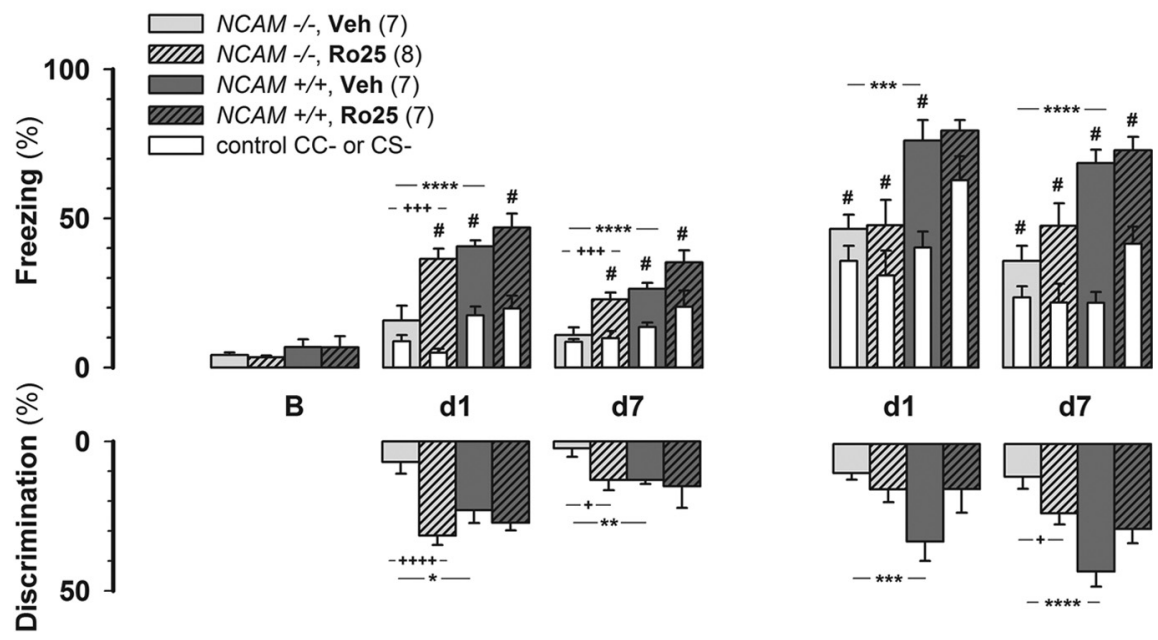

Figure 8. Intrahippocampal injection of Ro 25-6981 (Ro25) restores contextual memory in NCAM ${ }^{-1-}$ mice. A, Scheme of experiments with intrahippocampal injection of Ro25. $\mathrm{H} \& \mathrm{H}$, Habituation and handling of mice before the training session; TR, training; $T$, test session. Injection of either drug or vehicle $(V e h)$ was done 15 min before the beginning of the training session. Time is given in days ( $-\mathrm{d} 7$ and $-\mathrm{d} 2,7$ and $2 \mathrm{~d}$ before training; $\mathrm{d} 1$ and $\mathrm{d} 7$, days 1 and 7 after training); $\mathrm{CC}+$ and $\mathrm{CC}-$, conditioned and neutral contexts; $C S+$ and $C S$ - , conditioned and neutral stimuli. $\boldsymbol{B}$, Mean + SEM of freezing and discrimination levels before and after fear conditioning combined with intrahippocampal injection of Ro25. Contextual memory test (on the left): Levels of freezing before training (B, baseline) and on the two posttraining days, $\mathrm{d} 1$ and d7, in the conditioned context (filled bars) and in the control neutral context (empty bars). Tone memory test (on the right): Levels of freezing during presentation of the conditioned tone (filled bars) and the control tone (empty bars) at the two posttraining days, $\mathrm{d} 1$ and $\mathrm{d} 7$. Discrimination of $\mathrm{CC}+$ versus $\mathrm{CC}-$ and $\mathrm{CS}+$ versus $C S$ - was computed as the difference between $C \mathrm{C}+$ and $C \mathrm{C}-$ or $C S+$ and $C S-$ freezing responses, respectively. Four-way ANOVA of freezing time at different contexts revealed the effects of genotype $(p<0.001)$, $\operatorname{Ro25}(p<0.01)$, day $(p=0.001)$, context $(p<0.001)$ and interactions between context and Ro25 $(p<0.01)$; context, genotype and Ro25 $(p<0.05)$; and day and context ( $p<0.001)$. ANOVA of context discrimination revealed the effects of Ro25 $(p<0.01)$, day $(p<0.001)$ and interaction between genotype and Ro25 $(p<0.05)$. ANOVA of freezing time to different tones revealed the effects of genotype $(p<0.001)$, day $(p<0.001)$, tone $(p<0.001)$ and interactions between tone and genotype $(p=0.001)$; tone, genotype and Ro25 $(p<0.01)$; and day and tone $(p<0.01)$. ANOVA of tone discrimination revealed the effects of genotype ( $p=0.001)$, day $(p<0.01)$ and interaction between genotype and $\operatorname{Ro} 25(p<0.01) .{ }^{*} p<0.05,{ }^{* *} p<0.01,{ }^{* *} p<0.005,{ }^{* * * *} p<0.001$, significant differences between $N C A M^{+/+}$and NCAM ${ }^{-1-}$ untreated mice; ${ }^{+} p<0.05,{ }^{++} p<0.01,{ }^{+++} p<0.005$, ${ }^{++++} p<0.001$, significant differences between vehicle and Ro25-treated NCAM ${ }^{-1-}$ mice, Bonferroni post hoc $t$ test; ${ }^{\#} p<$ 0.05 , significant differences between freezing on $C \mathrm{C}+$ and $\mathrm{CC}-$ or $\mathrm{CS}+$ and $\mathrm{CS}-$, Wilcoxon test. Numbers of tested mice are indicated in parentheses.

deficient slices involve signaling via Ras-GRF1 to the Rac effector p38 MAPK: (1) The level of phosphorylated p38 MAPK is upregulated in NCAM-deficient mice and in endoNF-treated slices, while it is reduced in Ras-GRF1 ${ }^{-1-}$ mice (Li et al., 2006). (2) The level of phosphorylated p44 is co-upregulated although in a smaller degree than $\mathrm{p} 38$, as expected in response to activation of Ras-GRF1 (Li et al., 2006). (3) An inhibitor of p38 restores levels of LTP in PSA or NCAM-deficient slices to those seen in wildtype mice. (4) Ras-GRF1 is shown to mediate synaptic depression through p38 MAPK (Li et al., 2006). (5) Recordings of LTP in acute slices from $N C A M^{-/-}$mice of different ages (G. Kochlamazashvili, M. Schachner, and A. Dityatev, unpublished data) revealed that impairment in LTP appears after develop- mental switch in NMDA receptors downstream signaling from Sos to Ras-GRFs (Tian et al., 2004). (6) PSA deficiency does not lead to impaired LTP in Ras-GRF1 ${ }^{-/-}$ mice.

Activation of p38 MAPK signaling has also been shown to mediate impairment in LTP by tumor necrosis factor (Butler et al., 2004) and the $A \beta$ peptide generated from the amyloid precursor protein, which is widely believed to underlie the pathophysiology of Alzheimer's disease (Hsieh et al., 2006). p38 MAPK regulates the removal of synaptic AMPA and NMDA receptors from the postsynaptic cell surface, although the substrates for p38 that mediate these effects in response to tumor necrosis factor $\alpha, \mathrm{A} \beta$, or activation of NMDA receptors remain to be identified. Among the many molecules signaling downstream of p38 are transcription factors, protein kinases and the small GPTase Rab5, which is essential for early endocytosis (Shi and Gaestel, 2002). An attractive hypothesis is that activation of p38 MAPK may accelerate glutamate receptor endocytosis by stimulating the formation of the guanyl nucleotide dissociation inhibitor-Rab5 complex (Huang et al., 2004).

At the behavioral level, our data on the in vitro induction of LTP match the outcome of fear conditioning in $N_{C A M}^{-1-}$ mice. This paradigm has been used to show impairment in cued (amygdaladependent) and contextual (hippocampusand amygdala-dependent) fear memories in $N_{C A M}{ }^{-1-}$ mice (Stork et al., 2000) and in mice deficient for the polysialyltransferases ST8SiaII/STX or ST8SiaIV/ PST (Angata et al., 2004; Senkov et al., 2006). The importance of PSA in formation of hippocampus-dependent contextual memory is further underscored by the normalization of memory in $N C A M^{-/-}$ mice via application of PSA-NCAM, but not by NCAM without PSA (Senkov et al., 2006) and by disrupted contextual learning in wild-type mice after acute enzymatic removal of PSA from the dorsal hippocampus (Lopez-Fernandez et al., 2007). Here, we demonstrate that intrahippocampal injection of a GluN2B-specific antagonist normalizes contextual fear conditioning. Thus, PSA carried by NCAM regulates both synaptic plasticity and hippocampusdependent learning via modulation of NMDA receptors.

NCAM is a strong candidate gene for neurocognitive changes associated with schizophrenia (Sullivan et al., 2007). NCAM ${ }^{-/-}$ mice have enlarged lateral ventricles and deficits in prepulse inhibition of the acoustic startle (Wood et al., 1998), reminiscent of findings in schizophrenic patients. Furthermore, patients with schizophrenia have higher concentrations of the soluble cleaved extracellular domain of NCAM in prefrontal cortex, cingulate cortex, hippocampus, and CSF (Vawter et al., 2001; see their 
references). In addition to a deficit in PSA expression (Barbeau et al., 1995), a polymorphism in the promoter region of the polysialyltransferase ST8SiaII gene is associated with schizophrenia (Arai et al., 2006; Tao et al., 2007). Recently, cognitive dysfunction has been recognized as a primary and enduring core deficit in schizophrenia. Although new medications may improve other functions, they do not normalize neurocognitive deficits in schizophrenia (Peuskens et al., 2005). Thus, our demonstration that abnormalities in GluN2B-mediated signaling lead to cognitive abnormalities in NCAM/PSA-deficient brains may be an important contribution toward understanding the mechanisms of neurocognitive deficits in schizophrenia and their reversibility. The recent progress in dissection of the molecular mechanisms underlying single-gene mental disorders, such as tuberous sclerosis, neurofibromatosis type I, fragile X and Rett's syndromes (Kelleher and Bear, 2008), suggests novel treatments to restore synaptic and cognitive abnormalities in patients suffering from these disorders. Our study makes a step in a similar direction for schizophrenia and may encourage attempts to treat schizophrenia by targeting the GluN2B-p38 MAPK pathway.

\section{References}

Angata K, Chan D, Thibault J, Fukuda M (2004) Molecular dissection of the ST8Sia IV polysialyltransferase. Distinct domains are required for neural cell adhesion molecule recognition and polysialylation. J Biol Chem 279:25883-25890.

Arai M, Yamada K, Toyota T, Obata N, Haga S, Yoshida Y, Nakamura K, Minabe Y, Ujike H, Sora I, Ikeda K, Mori N, Yoshikawa T, Itokawa M (2006) Association between polymorphisms in the promoter region of the sialyltransferase 8B (SIAT8B) gene and schizophrenia. Biol Psychiatry 59:652-659.

Asztely F, Erdemli G, Kullmann DM (1997) Extrasynaptic glutamate spillover in the hippocampus: dependence on temperature and the role of active glutamate uptake. Neuron 18:281-293.

Barbeau D, Liang JJ, Robitalille Y, Quirion R, Srivastava LK (1995) Decreased expression of the embryonic form of the neural cell-adhesion molecule in schizophrenic brains. Proc Natl Acad Sci USA 92:2785-2789.

Bartlett TE, Bannister NJ, Collett VJ, Dargan SL, Massey PV, Bortolotto ZA, Fitzjohn SM, Bashir ZI, Collingridge GL, Lodge D (2007) Differential roles of NR2A and NR2B-containing NMDA receptors in LTP and LTD in the CA1 region of two-week old rat hippocampus. Neuropharmacology 52:60-70.

Becker CG, Artola A, Gerardy-Schahn R, Becker T, Welzl H, Schachner M (1996) The polysialic acid modification of the neural cell adhesion molecule is involved in spatial learning and hippocampal long-term potentiation. J Neurosci Res 45:143-152.

Bolshakov VY, Carboni L, Cobb MH, Siegelbaum SA, Belardetti F (2000) Dual MAP kinase pathways mediate opposing forms of long-term plasticity at CA3-CA1 synapses. Nat Neurosci 3:1107-1112.

Brennaman LH, Maness PF (2008) NCAM in neuropsychiatric and neurodegenerative disorders. Neurochem Res. Advance online publication. Retrieved March 13, 2008. doi:10.1007/s11064-008-9630-z.

Bukalo O, Fentrop N, Lee AY, Salmen B, Law JW, Wotjak CT, Schweizer M, Dityatev A, Schachner M (2004) Conditional ablation of the neural cell adhesion molecule reduces precision of spatial learning, long-term potentiation, and depression in the CA1 subfield of mouse hippocampus. J Neurosci 24:1565-1577.

Butler MP, O'Connor JJ, Moynagh PN (2004) Dissection of tumor-necrosis factor-alpha inhibition of long-term potentiation (LTP) reveals a p38 mitogen-activated protein kinase-dependent mechanism which maps to early-but not late-phase LTP. Neuroscience 124:319-326.

Collingridge GL, Olsen RW, Peters J, Spedding M (2009) A nomenclature for ligand-gated ion channels. Neuropharmacology 56:2-5.

Cremer H, Lange R, Christoph A, Plomann M, Vopper G, Roes J, Brown R, Baldwin S, Kraemer P, Scheff S (1994) Inactivation of the N-CAM gene in mice results in size reduction of the olfactory bulb and deficits in spatial learning. Nature 367:455-459.

Cremer H, Chazal G, Carleton A, Goridis C, Vincent JD, Lledo PM (1998)
Long-term but not short-term plasticity at mossy fiber synapses is impaired in neural cell adhesion molecule-deficient mice. Proc Natl Acad Sci U S A 95:13242-13247.

Dahme M, Bartsch U, Martini R, Anliker B, Schachner M, Mantei N (1997) Disruption of the mouse L1 gene leads to malformations of the nervous system. Nat Genet 17:346-349.

Dityatev A, Dityateva G, Schachner M (2000) Synaptic strength as a function of post- versus presynaptic expression of the neural cell adhesion molecule NCAM. Neuron 26:207-217.

Dityatev A, Dityateva G, Sytnyk V, Delling M, Toni N, Nikonenko I, Muller D, Schachner M (2004) Polysialylated neural cell adhesion molecule promotes remodeling and formation of hippocampal synapses. J Neurosci 24:9372-9382.

Eckhardt M, Bukalo O, Chazal G, Wang L, Goridis C, Schachner M, GerardySchahn R, Cremer H, Dityatev A (2000) Mice deficient in the polysialyltransferase ST8SiaIV/PST-1 allow discrimination of the roles of neural cell adhesion molecule protein and polysialic acid in neural development and synaptic plasticity. J Neurosci 20:5234-5244.

Gardoni F, Mauceri D, Malinverno M, Polli F, Costa C, Tozzi A, Siliquini S, Picconi B, Cattabeni F, Calabresi P, Di Luca M (2009) Decreased NR2B subunit synaptic levels cause impaired long-term potentiation but not long-term depression. J Neurosci 29:669-677.

Giese KP, Friedman E, Telliez JB, Fedorov NB, Wines M, Feig LA, Silva AJ (2001) Hippocampus-dependent learning and memory is impaired in mice lacking the Ras-guanine-nucleotide releasing factor 1 (Ras-GRF1). Neuropharmacology 41:791-800.

Hammond MS, Sims C, Parameshwaran K, Suppiramaniam V, Schachner M, Dityatev A (2006) Neural cell adhesion molecule-associated polysialic acid inhibits NR2B-containing N-methyl-D-aspartate receptors and prevents glutamate-induced cell death. J Biol Chem 281:34859-34869.

Holmes KD, Mattar PA, Marsh DR, Weaver LC, Dekaban GA (2002) The $\mathrm{N}$-methyl-D-aspartate receptor splice variant NR1-4 C-terminal domain. Deletion analysis and role in subcellular distribution. J Biol Chem 277:1457-1468.

Hsieh H, Boehm J, Sato C, Iwatsubo T, Tomita T, Sisodia S, Malinow R (2006) AMPAR removal underlies Abeta-induced synaptic depression and dendritic spine loss. Neuron 52:831-843.

Huang CC, You JL, Wu MY, Hsu KS (2004) Rap1-induced p38 mitogenactivated protein kinase activation facilitates AMPA receptor trafficking via the GDI. Rab5 complex. Potential role in (S)-3,5-dihydroxyphenylglyceneinduced long term depression. J Biol Chem 279:12286-12292.

Ivanov A, Pellegrino C, Rama S, Dumalska I, Salyha Y, Ben-Ari Y, Medina I (2006) Opposing role of synaptic and extrasynaptic NMDA receptors in regulation of the extracellular signal-regulated kinases (ERK) activity in cultured rat hippocampal neurons. J Physiol 572:789-798.

Katagiri H, Tanaka K, Manabe T (2001) Requirement of appropriate glutamate concentrations in the synaptic cleft for hippocampal LTP induction. Eur J Neurosci 14:547-553.

Kelleher RJ 3rd, Bear MF (2008) The autistic neuron: troubled translation? Cell 135:401-406.

Kohl BK, Dannhardt G (2001) The NMDA receptor complex: a promising target for novel antiepileptic strategies. Curr Med Chem 8:1275-1289.

Köhr G (2006) NMDA receptor function: subunit composition versus spatial distribution. Cell Tissue Res 326:439-446.

Köhr G, Jensen V, Koester HJ, Mihaljevic AL, Utvik JK, Kvello A, Ottersen OP, Seeburg PH, Sprengel R, Hvalby Ø (2003) Intracellular domains of NMDA receptor subtypes are determinants for long-term potentiation induction. J Neurosci 23:10791-10799.

Li S, Tian X, Hartley DM, Feig LA (2006) Distinct roles for Ras-guanine nucleotide-releasing factor 1 (Ras-GRF1) and Ras-GRF2 in the induction of long-term potentiation and long-term depression. J Neurosci 26:1721-1729.

Lopez-Fernandez MA, Montaron MF, Varea E, Rougon G, Venero C, Abrous DN, Sandi C (2007) Upregulation of polysialylated neural cell adhesion molecule in the dorsal hippocampus after contextual fear conditioning is involved in long-term memory formation. J Neurosci 27:4552-4561.

Lüthi A, Laurent JP, Figurov A, Muller D, Schachner M (1994) Hippocampal long-term potentiation and neural cell adhesion molecules L1 and NCAM. Nature 372:777-779.

Maness PF, Schachner M (2007) Neural recognition molecules of the immunoglobulin superfamily: signaling transducers of axon guidance and neuronal migration. Nat Neurosci 10:19-26. 
Massey PV, Johnson BE, Moult PR, Auberson YP, Brown MW, Molnar E, Collingridge GL, Bashir ZI (2004) Differential roles of NR2A and NR2B-containing NMDA receptors in cortical long-term potentiation and long-term depression. J Neurosci 24:7821-7828.

Muller D, Wang C, Skibo G, Toni N, Cremer H, Calaora V, Rougon G, Kiss JZ (1996) PSA-NCAM is required for activity-induced synaptic plasticity. Neuron 17:413-422.

Neyton J, Paoletti P (2006) Relating NMDA receptor function to receptor subunit composition: limitations of the pharmacological approach. J Neurosci 26:1331-1333.

Paxinos G FK (2001) The mouse brain in stereotaxic coordinates. San Diego: Academic.

Peuskens J, Demily C, Thibaut F (2005) Treatment of cognitive dysfunction in schizophrenia. Clin Ther 27 [Suppl A]:S25-S37.

Ponimaskin E, Voyno-Yasenetskaya T, Richter DW, Schachner M, Dityatev A (2007) Morphogenic signaling in neurons via neurotransmitter receptors and small GTPases. Mol Neurobiol 35:278-287.

Rodrigues SM, Schafe GE, LeDoux JE (2001) Intra-amygdala blockade of the NR2B subunit of the NMDA receptor disrupts the acquisition but not the expression of fear conditioning. J Neurosci 21:6889-6896.

Rutishauser U (2008) Polysialic acid in the plasticity of the developing and adult vertebrate nervous system. Nat Rev Neurosci 9:26-35.

Rutishauser U, Landmesser L (1996) Polysialic acid in the vertebrate nervous system: a promoter of plasticity in cell-cell interactions. Trends Neurosci 19:422-427.

Senkov O, Sun M, Weinhold B, Gerardy-Schahn R, Schachner M, Dityatev A (2006) Polysialylated neural cell adhesion molecule is involved in induction of long-term potentiation and memory acquisition and consolidation in a fear-conditioning paradigm. J Neurosci 26:10888-109898.

Sherwin AL (1999) Neuroactive amino acids in focally epileptic human brain: a review. Neurochem Res 24:1387-1395.

Shi Y, Gaestel M (2002) In the cellular garden of forking paths: how p38 MAPKs signal for downstream assistance. Biol Chem 383:1519-1536.

Stoenica L, Senkov O, Gerardy-Schahn R, Weinhold B, Schachner M, Dityatev A (2006) In vivo synaptic plasticity in the dentate gyrus of mice deficient in the neural cell adhesion molecule NCAM or its polysialic acid. Eur J Neurosci 23:2255-2264.

Stork O, Welzl H, Wolfer D, Schuster T, Mantei N, Stork S, Hoyer D, Lipp H, Obata K, Schachner M (2000) Recovery of emotional behaviour in neural cell adhesion molecule (NCAM) null mutant mice through transgenic expression of NCAM180. Eur J Neurosci 12:3291-3306.

Stummeyer K, Dickmanns A, Mühlenhoff M, Gerardy-Schahn R, Ficner R (2005) Crystal structure of the polysialic acid-degrading endosialidase of bacteriophage K1F. Nat Struct Mol Biol 12:90-96.

Südhof TC (2008) Neuroligins and neurexins link synaptic function to cognitive disease. Nature 455:903-911.

Sullivan PF, Keefe RS, Lange LA, Lange EM, Stroup TS, Lieberman J, Maness PF (2007) NCAM1 and neurocognition in schizophrenia. Biol Psychiatry 61:902-910.
Tang J, Wotjak CT, Wagner S, Williams G, Schachner M, Dityatev A (2001) Potentiated amygdaloid auditory-evoked potentials and freezing behavior after fear conditioning in mice. Brain Res 919:232-241.

Tang J, Wagner S, Schachner M, Dityatev A, Wotjak CT (2003) Potentiation of amygdaloid and hippocampal auditory-evoked potentials in a discriminatory fear-conditioning task in mice as a function of tone pattern and context. Eur J Neurosci 18:639-650.

Tang YP, Shimizu E, Dube GR, Rampon C, Kerchner GA, Zhuo M, Liu G, Tsien JZ (1999) Genetic enhancement of learning and memory in mice. Nature 401:63-69.

Tao R, Li C, Zheng Y, Qin W, Zhang J, Li X, Xu Y, Shi YY, Feng G, He L (2007) Positive association between SIAT8B and schizophrenia in the Chinese Han population. Schizophr Res 90:108-114.

Tian X, Gotoh T, Tsuji K, Lo EH, Huang S, Feig LA (2004) Developmentally regulated role for Ras-GRFs in coupling NMDA glutamate receptors to Ras, Erk and CREB. EMBO J 23:1567-1575.

Tsvetkov E, Shin RM, Bolshakov VY (2004) Glutamate uptake determines pathway specificity of long-term potentiation in the neural circuitry of fear conditioning. Neuron 41:139-151.

Ueda Y, Doi T, Tokumaru J, Mitsuyama Y, Willmore LJ (2000) Kindling phenomena induced by the repeated short-term high potassium stimul in the ventral hippocampus of rats: on-line monitoring of extracellular glutamate overflow. Exp Brain Res 135:199-203.

Vaithianathan T, Manivannan K, Kleene R, Bahr BA, Dey MP, Dityatev A, Suppiramaniam V (2005) Single channel recordings from synaptosomal AMPA receptors. Cell Biochem Biophys 42:75-85.

Vawter MP, Usen N, Thatcher L, Ladenheim B, Zhang P, VanderPutten DM, Conant K, Herman MM, van Kammen DP, Sedvall G, Garver DL, Freed WJ (2001) Characterization of human cleaved N-CAM and association with schizophrenia. Exp Neurol 172:29-46.

Weinhold B, Seidenfaden R, Röckle I, Mühlenhoff M, Schertzinger F, Conzelmann S, Marth JD, Gerardy-Schahn R, Hildebrandt H (2005) Genetic ablation of polysialic acid causes severe neurodevelopmental defects rescued by deletion of the neural cell adhesion molecule. J Biol Chem 280:42971-42977.

Wood GK, Tomasiewicz H, Rutishauser U, Magnuson T, Quirion R, Rochford J, Srivastava LK (1998) NCAM-180 knockout mice display increased lateral ventricle size and reduced prepulse inhibition of startle. Neuroreport 9:461-466.

Zhao MG, Toyoda H, Lee YS, Wu LJ, Ko SW, Zhang XH, Jia Y, Shum F, Xu H, Li BM, Kaang BK, Zhuo M (2005) Roles of NMDA NR2B subtype receptor in prefrontal long-term potentiation and contextual fear memory. Neuron 47:859-872.

Zhou ZL, Cai SX, Whittemore ER, Konkoy CS, Espitia SA, Tran M, Rock DM, Coughenour LL, Hawkinson JE, Boxer PA, Bigge CF, Wise LD, Weber E, Woodward RM, Keana JF (1999) 4-Hydroxy-1-[2-(4-hydroxyphenoxy)ethyl]-4-(4-methylbenzyl)piperidine: a novel, potent, and selective NR1/2B NMDA receptor antagonist. J Med Chem 42:2993-3000. 